\title{
The Density of EAAC1 (EAAT3) Glutamate Transporters Expressed by Neurons in the Mammalian CNS
}

\author{
Silvia Holmseth, ${ }^{1}$ Yvette Dehnes, ${ }^{1}$ Yanhua H. Huang, ${ }^{3}$ Virginie V. Follin-Arbelet, ${ }^{1}$ Nina J. Grutle, ${ }^{1}$ Maria N. Mylonakou, ${ }^{1}$ \\ Celine Plachez, ${ }^{4}$ Yun Zhou, ${ }^{1}$ David N. Furness, ${ }^{2}$ Dwight E. Bergles, ${ }^{3}$ Knut P. Lehre, ${ }^{1}$ and Niels C. Danbolt ${ }^{1}$ \\ ${ }^{1}$ Centre for Molecular Biology and Neuroscience, Department of Anatomy, Institute of Basic Medical Sciences, University of Oslo, N-0317 Oslo, Norway, \\ ${ }^{2}$ Institute for Science and Technology in Medicine, Keele University, Keele, Staffs ST5 5BG, United Kingdom, ${ }^{3}$ The Solomon H. Snyder Department of \\ Neuroscience, The Johns Hopkins University School of Medicine, Baltimore, Maryland 21205, and ${ }^{4}$ Department of Anatomy and Neurobiology, University \\ of Maryland, Baltimore, Maryland 21201
}

The extracellular levels of excitatory amino acids are kept low by the action of the glutamate transporters. Glutamate/aspartate transporter (GLAST) and glutamate transporter-1 (GLT-1) are the most abundant subtypes and are essential for the functioning of the mammalian CNS, but the contribution of the EAAC1 subtype in the clearance of synaptic glutamate has remained controversial, because the density of this transporter in different tissues has not been determined. We used purified EAAC1 protein as a standard during immunoblotting to measure the concentration of EAAC1 in different CNS regions. The highest EAAC1 levels were found in the young adult rat hippocampus. Here, the concentration of EAAC1 was $\sim 0.013 \mathrm{mg} / \mathrm{g}$ tissue $\left(\sim 130\right.$ molecules $\left.\mu \mathrm{m}^{-3}\right), 100$ times lower than that of GLT-1. Unlike GLT-1 expression, which increases in parallel with circuit formation, only minor changes in the concentration of EAAC1 were observed from E18 to adulthood. In hippocampal slices, photolysis of MNI-D-aspartate (4-methoxy-7-nitroindolinyl-D-aspartate) failed to elicit EAAC1-mediated transporter currents in CA1 pyramidal neurons, and D-aspartate uptake was not detected electron microscopically in spines. Using EAAC1 knock-out mice as negative controls to establish antibody specificity, we show that these relatively small amounts of EAAC1 protein are widely distributed in somata and dendrites of all hippocampal neurons. These findings raise new questions about how so few transporters can influence the activation of NMDA receptors at excitatory synapses.

\section{Introduction}

Extracellular glutamate must be maintained at a low level and removed rapidly after synaptic release to ensure high fidelity transmission and to prevent excitotoxicity. Clearance of glutamate is catalyzed by glutamate transporters, of which the glutamate/aspartate transporter (GLAST, also known as EAAT1) and glutamate transporter-1 (GLT-1, also known as EAAT2) subtypes are particularly important (Danbolt, 2001). In contrast, the role of EAAC1 (EAAT3) is still debated. Immunoisolation of transport activity (Haugeto et al., 1996), deletion of the GLT-1 (slcla2) gene (Bergles and Jahr, 1997, 1998; Tanaka et al., 1997;

Received 0ct. 24, 2011; revised Feb. 23, 2012; accepted March 12, 2012.

Author contributions: S.H., Y.D., Y.Z., D.N.F., D.E.B., K.P.L., and N.C.D. designed research; S.H., Y.D., Y.H.H., V.V.F.-A., N.J.G., M.N.M., C.P., Y.Z., D.N.F., D.E.B., K.P.L., and N.C.D. performed research; S.H. and Y.D. contributed unpublished reagents/analytic tools; S.H., Y.D., V.V.F.-A., N.J.G., C.P., Y.Z., D.N.F., D.E.B., K.P.L., and N.C.D. analyzed data; S.H., D.E.B., K.P.L., and N.C.D. wrote the paper.

This work was supported by the Norwegian Research Council (fellowships to Y.D., K.P.L.) and National Institutes of Health Grant MH084020 (D.E.B.). N.C.D. acknowledges the economic support of the Norwegian Advanced Research Program (Toppforskningsprogrammet covering the salary of S.H.), FUGE II (183727-S10), and a private donation that financed the synthesis of the $\mathrm{C} 510$ and the (491 peptides. We thank Kohichi Tanaka for the GLT-1 knockout mice and Henriette Danbolt for technical assistance. We are especially grateful to Rolf Seljelid, without whose encouragement and support the project would not have been possible.

Correspondence should be addressed to either Knut P. Lehre or Niels C. Danbolt, Department of Anatomy, Institute of Basic Medical Sciences, University of Oslo, P.O. Box 1105 Blindern, N-0317 Oslo, Norway. E-mail: k.p.d.lehre@medisin.uio.no or n.c.danbolt@medisin.uio.no.

Y. H. Huang's present address: Program in Neuroscience, Washington State University, Pullman, WA 99164.

DOI:10.1523/JNEUROSCI.5347-11.2012

Copyright $\odot 2012$ the authors $\quad 0270-6474 / 12 / 326000-14 \$ 15.00 / 0$
Sun et al., 2011), and the mild phenotype of EAAC1-deficient mice (Peghini et al., 1997) suggest that EAAC1-mediated glutamate uptake is negligible compared with that of GLT-1. However, EAAC1-deficient mice suffer from dicarboxylic aminoaciduria (Peghini et al., 1997) and premature aging (Chen and Swanson, 2003; Aoyama et al., 2006; Berman et al., 2011). Although recent results suggest that EAAC1-deficient mice are impaired in some learning and memory paradigms (Lee et al., 2012), this has not been universally reported (Aoyama et al., 2006), and these mice do not exhibit the overt CNS abnormalities observed in GLT-1and GLAST-deficient mice (Tanaka et al., 1997; Watase et al., 1998). Observations of humans with defective EAAC1 are in line with this view (Bailey et al., 2011). By contrast, antisense knockdown of EAAC1 indicated that this transporter accounts for $\sim 40 \%$ of the glutamate uptake activity in the hippocampus (Rothstein et al., 1996), and high-resolution immunolabeling studies (He et al., 2000, 2001) concluded that EAAC1 is present in dendritic shafts and in spines surrounding active zones as well as in terminals.

In vitro physiological studies support the conclusion that EAAC1 is an important component of the glutamate clearance machinery at synapses. At hippocampal synapses in EAAC1deficient mice, glutamate transporter currents in astrocytes decay more rapidly, suggesting that the predominant action of EAAC1 is to buffer, rather than rapidly transport glutamate (Scimemi et al., 2009). This buffering effect increases the probability of glutamate capture by GLAST and GLT-1 that are present at high 
densities in astrocytes (Lehre and Danbolt, 1998). By this mechanism, EAAC1 may limit activation of perisynaptic NMDA receptors and increase the threshold for induction of long-term potentiation (Scimemi et al., 2009). In addition, functional studies suggest that EAAC1 is also present in GABAergic nerve terminals, where it may help maintain GABA levels by providing glutamate for GABA synthesis (Sepkuty et al., 2002; Mathews and Diamond, 2003; Stafford et al., 2010), suggesting that EAAC1 is abundant in both presynaptic and postsynaptic membranes.

The lack of consensus regarding the role of EAAC1 is, in part, due to the lack of information regarding the abundance of this transporter in neuronal membranes. To define the amount of EAAC1 available to participate in extracellular glutamate clearance, we validated the specificity of EAAC1 antibodies using tissue from EAAC1-deficient mice, and quantified the amounts of EAAC1 protein relative to GLT-1 protein. We show that EAAC1 is $\sim 100$-fold less abundant than GLT-1 in the young adult rat hippocampus. EAAC1 was observed in the dendrites of all neurons, but was not in synaptic terminals. These data support the hypothesis that EAAC1 plays a role in neuronal metabolism rather than neurotransmission.

\section{Materials and Methods \\ Materials}

SDS of high purity ( $>99 \%$ C12 alkyl sulfate), bis(sulfosuccinimidyl)suberate, and SuperSignal West Dura were from Pierce, and electrophoresis equipment were from Hoefer Scientific Instruments. $N, N^{\prime}$-Methylenebisacrylamide, acrylamide, ammonium persulfate, TEMED $\left(N, N, N^{\prime}, N^{\prime}\right.$ tetramethylethylenediamine), and alkaline phosphatase substrates (nitroblue tetrazolium and 5-bromo-4-chloro-3-indolyl phosphate) were from Promega. Protein A-Sepharose Fast Flow and Sephadex G-50 fine were from GE Healthcare. Molecular mass markers for SDS-PAGE, ECL films, and nitrocellulose sheets $(0.22 \mu \mathrm{m}$ pores; $100 \%$ nitrocellulose $)$ were from GE Healthcare. Paraformaldehyde and glutaraldehyde EM grade were from TAAB. Lowicryl HM20 was from Electron Microscopy Sciences. BSA, 3-[(3cholamido-propyl)dimethylammonio]-1-propanesulphonate (CHAPS), dimethyl suberimidate, dithiotreitol, EDTA, HEPES, human serum albumin, phenylmethanesulfonyl fluoride (PMSF), Trizma base, Trisma-HCl, Triton X-100, and wheat germ agglutinin were obtained from SigmaAldrich. Wheat germ agglutinin was immobilized on agarose as described previously (Danbolt et al., 1992). Pure GLT-1 glutamate transporter protein was from the same batches as previously produced (Lehre and Danbolt, 1998).

\section{Antibodies}

Anti-peptide antibodies against glutamate transporters were from the same batches as described previously. The batch numbers are given below together with reference: The anti-GLAST antibodies were the rabbit anti-A522 antibody (Ab\#141) (Lehre et al., 1995) and a mouse monoclonal anti-GLAST antibody (lot 124102; NCL-EAAT1; Novocastra Laboratories) (Banner et al., 2002). Both of these were directed to a peptide (PYQLIAQDNEPEKPVADS ET-amide) representing residues 522-541 of rat GLAST (Storck et al., 1992). The anti-GLT-1 antibodies were the monoclonal 9C4 antibody (Ab\#531) (Levy et al., 1993), the anti-B12 (Ab\#360) (Holmseth et al., 2005) to residues 12-26 of rat GLT-1 (KQVEVRMHDSHLSSE-amide) (Pines et al., 1992), and a monoclonal antibody NCL-EAAT2 (lot 118003; Novocastra Laboratories) (Milton et al., 1997). Three synthetic peptides representing parts of EAAC1 (Kanai and Hediger, 1992; Bjørås et al., 1996) were used to produce the anti-EAAC1 antibodies used in the present report: C479 (IVNPFALEPT ILDNEDSDTK-amide), C491 (CLDNEDSDTKKSYVNGGFSVDKSDTISF TQTSQF-free acid), and C510 (VDKSDTISFTQTSQF-free acid). The rabbit antibodies to the C479 peptide (anti-C479; Ab\#359) cross-reacted with tubulin and were therefore absorbed against immobilized tubulin before being used in the present study (Holmseth et al., 2005). The anti-C491 antibodies were from several different batches (Ab\#237, $\mathrm{Ab} \# 236, \mathrm{Ab} \# 371$, and $\mathrm{Ab} \# 555$ ) and have also been described previously (Holmseth et al., 2005). The antiC510 antibodies were both from rabbit (Ab\#126) (Haugeto et al., 1996) and
Table 1. Isolation of EAAC1 protein from rat kidney

\begin{tabular}{lllllll}
\hline Detergent & Rat age & $\begin{array}{l}\text { Antibody } \\
\text { ID }\end{array}$ & $\begin{array}{l}\text { Amount of pure } \\
\text { EAAC1 protein } \\
\text { obtained }(\mu \mathrm{g})\end{array}$ & WGA & DEAE & $\begin{array}{l}\text { Sample } \\
\text { ID }\end{array}$ \\
\hline Cholate & $220-240 \mathrm{~g}$ & Ab\#237 & 88 & No & Yes & 1374 \\
SDS & 9 weeks & Ab\#555 & 12 & Yes & No & 1357 \\
SDS & 9 weeks & Ab\#555 & 20 & Yes & No & 1358 \\
\hline
\end{tabular}

Rat kidneys were solubilized in cholate or SDS and EAAC1 isolated using immobilized anti-C491 antibodies (either Ab\#237 or Ab\#555). The bound EAAC1 protein was eluted at low pH, neutralized, and further purified by chromatography on either a wheat germ agglutinin lectin (WGA) column or a DEAE column as indicated. The age is given in weight (grams) or in weeks.

from sheep (Ab\#340) (Holmseth et al., 2005) (\#14000\}). The latter batch was further purified by passing it through a column with aldehyde-treated bacterial proteins to remove unwanted antibodies (Danbolt et al., 1998). The antibodies that did not stick to the column were highly specific (Ab\#565) (Holmseth et al., 2012). Anti-glutamine synthetase (MAB 302) was from Millipore Bioscience Research Reagents, anti-NG2 (sc-20162) was from Santa Cruz Biotechnology, and anti-myelin basic protein (MBP) and antiCNPase were Sternberger Monoclonals. Anti-VGLUT1 (clone 317D5) was from SYSY. Anti-parvalbumin (P3088; lot 30K4824), anti-glial fibrillary acid protein (G3893; lot 082K4834), anti-glutamine synthetase (G2781; lot 061K4811), anti-synaptophysin (S5768), anti-GAD (G1166; clone GAD-6), alkaline phosphatase- and peroxidase-conjugated monoclonal antibodies to mouse, rabbit, and sheep IgG (A5187, A9452, A2179, A2556, A9044, and A1949) were from Sigma-Aldrich. Biotinylated anti-rabbit, anti-sheep, and anti-mouse Igs, streptavidin-biotinylated horseradish peroxidase complex, and colloidal gold-labeled anti-rabbit and anti-mouse Igs were from GE Healthcare. Alexa Fluor goat anti-rabbit 555, goat anti-mouse 488, and donkey anti-sheep 555 were from Invitrogen. Other reagents were obtained from Fluka. The fluorescein Lotus tetragonolobus lectin (FL-1321; lot W0909) was from Vector Laboratories.

\section{Animals}

All animal experimentation was performed in accordance with the $\mathrm{Na}$ tional Institutes of Health Guide for the Care and Use of Laboratory Animals (NIH publication no. 80-23, revised 1996) and the European Communities Council Directive of 24 November 1986 (86/609/EEC). Formal approval to conduct the experiments described was obtained from the animal subjects review board of our institutions. Care was taken to avoid suffering and to minimize the number of animals used. Adult male Wistar rats (9-12 weeks of age as indicated) and C57Black/6 (3 weeks of age) obtained from B\&K Universal were kept in the animal facility at the Institute of Basic Medical Sciences. Brain tissue for immunocytochemistry was obtained from rats that had been killed by injection of pentobarbital and fixed by cardiac perfusion as described previously (Danbolt et al., 1998). The generation of mice lacking EAAC1 and their genotyping have been described in detail previously (Peghini et al., 1997). Experiments were performed on EAAC1 wild-type and knock-out mice (3-4 weeks of age).

\section{Electrophoresis and blotting}

SDS-PAGE was performed as described previously (Lehre et al., 1995) with separating gels consisting of 7.5 or $10 \%$ acrylamide, or with $4-20 \%$ gradient gels. After electrophoresis, the proteins were either silver stained or electroblotted onto nitrocellulose membranes. Because the purpose of the immunoblotting was to maximize the probability of detecting possible unwanted immunoreactivity toward non-EAAC1 proteins, the samples were prepared by homogenizing whole tissue directly in SDS so that the blots would contain as many of the tissue antigens as possible [for discussion of antibody specificity and testing, see Holmseth et al. (2005)].

Qualitative immunolabeling of blots (see Fig. 1) was done using alkaline phosphatase-conjugated secondary antibodies exactly as described previously (Lehre et al., 1995). This detection system has low contrast and is therefore suitable for detection of cross-reactivity. As shown (see Fig. $1 A-C$ ), the antibodies used in this study labeled one weak, but relatively broad fuzzy band at $\sim 70 \mathrm{kDa}$ on immunoblots of fresh tissue from brain and kidney directly solubilized in SDS. Some weak bands representing non-EAAC1 proteins were also observed (see Fig. 1A, strip 1), 
but the band representing EAAC1 was absent on blots prepared from tissue from EAAC1-deficient mice (see Fig. $1 D$ ). This implied that the immunolabeling of this band could be used as a measure of the amount of EAAC1.

Immunoaffinity purification of EAAC1 from rat kidney

The purpose was to obtain pure EAAC1 protein that could be, in known amounts, immunoblotted together with brain protein extracts. This is a method we have successfully used before to quantify the concentrations of GLAST, GLT-1, and EAAT4 (Dehnes et al., 1998; Lehre and Danbolt, 1998). Since EAAC1 was originally cloned from rabbit intestine 20 years ago (Kanai and Hediger, 1992), there has to our knowledge been no reports of variants. EAAC1 in the intestine, in the kidney, and in the brain are thought to be identical. In pilot experiments, both brain and kidney were used as sources of EAAC1 protein. These experiments did not give any indications that brain and kidney EAAC1 were different from each other, and kidney was chosen as the source because it was easier to obtain large amounts of the protein in pure form from there. It is important to note that the purification method described below uses antibodies to the $\mathrm{C}$ terminus to isolate EAAC1. This means that any hypothetical variant of EAAC1 being different in this region would not have been isolated and would therefore not affect the measurements. Such a hypothetical variant would also be invisible during the immunocytochemical studies (see below).

Antibodies ( $0.5 \mathrm{mg}$ of anti-C491; Ab\#236 or $\mathrm{Ab \# 555)}$ were immobilized on protein A-Sepharose Fast Flow $(0.5 \mathrm{ml})$ and covalently linked using dimethyl suberimidate (Danbolt et al., 1992). EAAC1 protein was purified three times (Table 1) using the following procedure: 20 kidneys ( $\sim 3$ g of protein) were freshly dissected from Wistar rats and homogenized in 10 vol of ice-cold hypotone buffer (5 mM EDTA, 1 mM PMSF) using a Polytron7 PT1200 homogenizer followed by treatment in a Dounce glass-glass homogenizer. The mixture was centrifuged $\left(20 \mathrm{~min}, 39,000 \times \mathrm{g}, 4^{\circ} \mathrm{C}\right.$; Beckman JA20 rotor). The pellet was solubilized either in $10 \mathrm{vol}$ of solubilization buffer $(0.5 \%$ lithium dodecyl sulfate, 45 mm Li-HEPES, pH 7.5, 90 mM LiCl, 4.5 mM EDTA, and 0.9 mM PMSF) or in $2 \%$ cholate (Lehre and Danbolt, 1998) as indicated (Table 1). The mixture was sonicated (30 s, on ice, with a Hielscher type UP50H sonicator) to reduce viscosity by breaking up DNA and then incubated ( 5 min on ice). When lithium dodecyl sulfate had been used, then Triton X-100 was added to a final concentration of $25-30 \mathrm{mg} / \mathrm{ml}$ to make the solution "antibody friendly." The resultant mixture was incubated ( 5 min on ice), and centrifuged $(39,000 \times g, 20$ min, $4^{\circ} \mathrm{C}$; Beckman JA20 rotor). The supernatant was incubated end-over-end (90-270 min; $4^{\circ} \mathrm{C}$ ) with the immobilized antibodies (see above). The antibody beads were washed (three times for 6 min each; $4^{\circ} \mathrm{C}$ ) with buffer $(0.3 \mathrm{~m} \mathrm{NaCl}, 20 \mathrm{~mm}$ CHAPS, $40 \mathrm{~mm}$ sodium phosphate buffer, $\mathrm{pH}$ 7.4). Bound proteins were eluted (two times for $5 \mathrm{~min}$ each; $\left.4^{\circ} \mathrm{C}\right)$ with low-pH buffer $(0.15 \mathrm{M}$ $\mathrm{NaCl}, 20 \mathrm{~mm}$ CHAPS, $0.32 \mathrm{~m}$ glycine- $\mathrm{HCl}, \mathrm{pH} 2.0$ ). The eluate was immediately neutralized by adding $1 / 10 \mathrm{vol}$ of $2 \mathrm{~m}$ Tris- $\mathrm{HCl}, \mathrm{pH}$ 9. EDTA and PMSF were added to final concentrations of 5 and $1 \mathrm{~mm}$, respectively. The eluate was then passed through a DEAE-cellulose column or a wheat germ agglutinin-agarose column as indicated (Table 1). The wheat germ agglutinin column was washed with 2 vol of washing buffer $(20 \mathrm{~mm}$ CHAPS, $0.5 \mathrm{M} \mathrm{NaCl}$, and $20 \mathrm{~mm}$ sodium phosphate buffer, $\mathrm{pH} 7.4$ ), and bound proteins were eluted with NAG-buffer $(0.200 \mathrm{~mm}$ $\mathrm{N}$-acetylglucosamine, $20 \mathrm{~mm}$ CHAPS, $0.5 \mathrm{M} \mathrm{NaCl}$, and $20 \mathrm{~mm}$ sodium
Table 2. Quantification of EAAC1 protein in rat brain tissue

\begin{tabular}{llllll}
\hline Animal & Age & Region & Type & Detection system & $\begin{array}{l}\text { Milligrams of EAAC1 per } \\
\text { gram total protein }\end{array}$ \\
\hline $1-3$ & $220 \mathrm{~g}$ & Hippoc & Whole & ${ }^{125}$ I-Prot A & $0.17 \pm 0.02$ (3 animals) \\
$1-3$ & $220 \mathrm{~g}$ & Cerebel & Whole & ${ }^{125}$ I-Prot A & $0.03 \pm 0.01$ (3 animals) \\
$4-6$ & $220 \mathrm{~g}$ & Hippoc & Membr & ${ }^{125}$ I-Prot A & $0.25 \pm 0.01$ (3 animals) \\
$7-9$ & 8 weeks, F & Hippoc & Membr & ${ }^{125}$ I-Prot A & $0.17 \pm 0.01$ (3 animals) \\
$10-12$ & 14 weeks & Hippoc & Whole & Chemilum & $0.09 \pm 0.01$ (3 animals) \\
$13-19$ & 9 weeks & Hippoc & Whole & Chemilum & $0.15 \pm 0.01$ (7 animals)
\end{tabular}

The amounts of EAAC1 protein in tissue from the hippocampus (Hippoc) and cerebellum (Cerebel) were measured by immunoblotting using purified preparations of EAAC1 protein (Table 1) as standards. The measurements of the levels in animals 1-9 are based on anti-C491 (Ab\#237) and the first EAAC1 preparation (Table 1, sample no. 1374), while the other measurements (animal 10 -19) are based on anti-C491 (Ab\#555) and the two other EAAC1 preparations. Bound antibodies were detected either with iodinated protein $A$ or with chemiluminiscence (Chemilum) as indicated. Note that the cerebellum contains less EAAC1 than the hippocampus in agreement with Figure 3. Also note that some tissue samples were homogenized in water to remove water-soluble proteins before solubilization in SDS. These are indicated (Membr) in contrast to the rest, which were solubilized directly (Whole). Water-soluble proteins represent $\sim 50 \%$ of the total brain proteins but do not contain any detectable amounts of EAAC1 (data no shown). The water-insoluble fraction (Membr) is therefore twofold enriched with respect to EAAC1. The age is given in weight (grams) or in weeks. All animals were males except those indicated (F).

${ }^{a}$ Values represent mean \pm SEM.

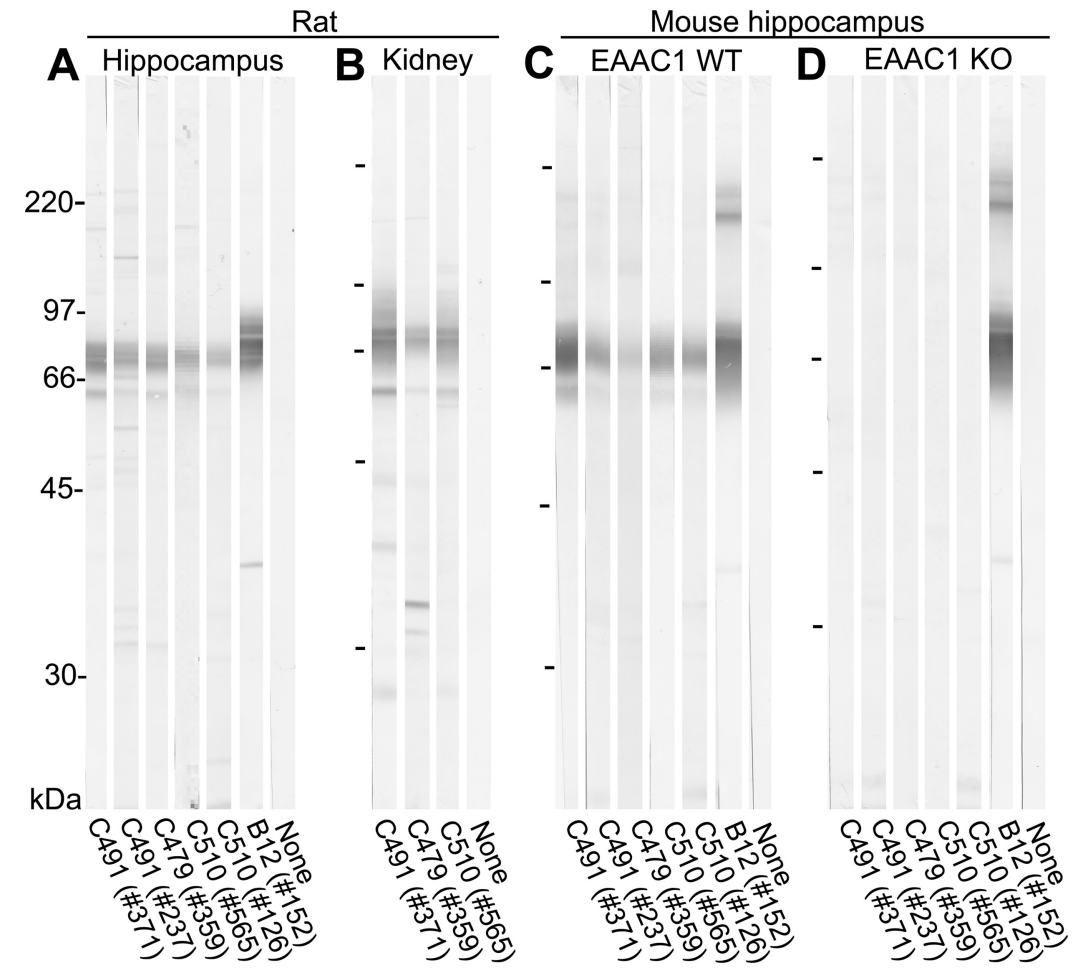

Figure 1. The specificity of the EAAC1 antibodies as demonstrated by immunoblotting of electrophoretically separated proteins from rat hippocampus $(\boldsymbol{A})$, rat kidney $(\boldsymbol{B})$, and wild-type $(\boldsymbol{C})$ and EAAC1 knock-out $(\boldsymbol{D})$ mice hippocampi. The blot strips were, as indicated, incubated with anti-C491 (Ab\#371), anti-C491 (Ab\#237), anti-C479 (Ab\#359), sheep anti-C510 (Ab\#565), anti-C510 (Ab\#126), anti-B12 (Ab\#152 as positive control), and no primary antibody ("None" as negative control). Each strip contained $16 \mu \mathrm{g}$ of protein. The absence of labeling in EAAC1 knock-out mice $(\boldsymbol{D})$ attests the specificity of the antibodies. All antibodies were used at a concentration of $1 \mu \mathrm{g} / \mathrm{ml}$ except for anti-B12, which was used at $0.2 \mu \mathrm{g} / \mathrm{ml}$. The apparent molecular mass is larger than the predicted molecular mass ( $58 \mathrm{kDa}$ ). This is at least in part due to glycosylation (Danbolt, 2001).

phosphate buffer, $\mathrm{pH}$ 7.4). Aliquots of the eluate destined for SDS-PAGE were mixed with SDS sample buffer containing $50 \mathrm{~mm}$ dithiothreitol and frozen. SDS was added to stop the irreversible aggregation of transporters that occurs in mild detergents [for a discussion of SDS-insoluble multimers of glutamate transporters, see section 7.4.2 in the study by Danbolt (2001)].

Using this procedure, highly purified rat kidney EAAC1 protein (see Fig. 2, lanes 5-8) was obtained. There was no detectable leak of IgG from the affinity column. The IgG heavy chains give rise to a band just below that of EAAC1 (data not shown). However, SDS-insoluble higher molec- 
ular mass aggregates formed during the purification procedure until the samples could be stabilized by the addition of SDS. This complicated protein measurement because nonaggregated and aggregated versions of the protein have different molecular masses and thereby have different blot transfer efficacies. Because only the monomer is seen on blots made from extracts prepared by direct solubilization of fresh tissue in SDS (see Fig. $3 A$ ), only the monomer was useful as standard for immunoblotting. This implied that it was not helpful to measure the protein concentration in the purified preparation of EAAC1 using standard procedures. It was necessary to measure the concentration of the monomer independently of oligomers. The concentrations of the intact monomer in the purified preparations of EAAC1 (Table 1) were therefore determined densitometrically on silver-stained polyacrylamide gels (Danbolt et al., 1990) using purified GLT-1 as a standard (see Fig. 2). GLT-1-protein was chosen because this is a closely related protein, which thereby presumably reacts similarly with the silver stain, because it was available in sufficient quantities to allow precise determination of its concentrations by a number of protein assays (including both the Lowry and the BCA assays) (Lehre and Danbolt, 1998), and because we have been able to produce this protein in nonaggregated form as shown (see Fig. 2). The stained gels were scanned using translumination on an Epson Expression 1680 Pro7 scanner, and the density of the bands was determined both with NIH ImageJ and with ImageMaster TotalLab (GE Healthcare). The two programs gave the same results. Because the immunoaffinity isolation method is expensive with regard to antibodies, the antigen was always added in excess to ensure saturation of the antibodies. Under these conditions, $0.5 \mathrm{ml}$ of gel containing $0.5 \mathrm{mg}$ of immobilized antibodies gave $90-130 \mu \mathrm{g}$ of EAAC1 protein and $12-20 \mu \mathrm{g}$ remained after the final purification on the wheat germ agglutinin column.

It was noted that the electrophoretic mobility of EAAC1 from striatum was slightly lower than that of EAAC1 from the other brain regions tested (data not shown), resembling the situation with cerebellar GLAST (EAAT1), which runs more slowly than that from the rest of the brain (Lehre et al., 1995).

\section{Immunolabeling of blots for quantitative measurements}

Quantitative measurements were made either using ${ }^{125} \mathrm{I}$-protein A exactly as described previously (Beckstrøm et al., 1999) in combination with anti-C491 (Ab\#237; 0.1-3 $\mu \mathrm{g} / \mathrm{ml})$ or using chemiluminescence ( $\mathrm{Su}-$ persignal West Dura from Pierce) as described previously (Holmseth et al., 2009) in combination with anti-C491 (Ab\#371; $0.125 \mu \mathrm{g} / \mathrm{ml})$. The immunoreactivities per unit protein in whole-tissue homogenates of hippocampus, cerebellum, and kidney were compared with that of three purified preparations of EAAC1 (Table 1). The hippocampal and cerebellar homogenates contained all tissue components because SDS dissolves brain tissue completely (a clear solution is obtained). The kidney, however, contains water and SDS-insoluble components (connective tissue). Therefore, the kidney homogenates refer only to the components that could be solubilized. When stated (Table 2), hippocampus was first homogenized in water and subjected to high-speed centrifugation $\left(39,000 \times g, 20 \mathrm{~min}, 4^{\circ} \mathrm{C}\right.$; Beckman JA20 rotor). The pellet was dissolved in SDS as above and referred to as "Membranes" in Table 2. To determine the regional differences in EAAC1 levels (see Fig. 3), whole-tissue homogenates were made from cerebellum, neocortex, olfactory bulb, striatum, thalamus/hypothalamus, pons, and mesencephalon. The immunoreactivities of these homogenates were compared with that of hippocampus using the chemiluminescence-based method only. The samples were run in triplicate and compared with hippocampus (see Fig. $3 A$ ).

Note that this immunoblotting method did not have the sensitivity issues that labeling of tissue sections had. For instance, the tissue used for immunoblotting was solubilized in SDS, eliminating most protein-protein interactions as well as the 3D structure. Furthermore, the proteins were not exposed to fixatives that can create or destroy epitopes (Holmseth et al., 2012).

\section{Immunocytochemistry}

Perfusion fixation of animals, Vibratome sectioning, immunoperoxidase staining of Vibratome sections, and preembedding electron microscopy

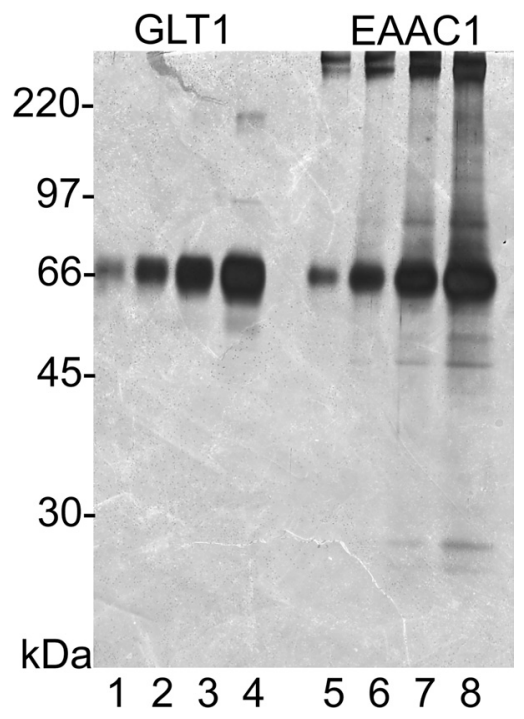

Figure 2. Determination of the concentration of monomeric EAAC1-protein in the purified preparations of EAAC1 protein. Highly purified GLT-1 protein $(50,100,200$, and $350 \mathrm{ng}$ in lanes $1-4$, respectively) and a purified preparation of $\operatorname{EAAC1}(5,10,20$, and $35 \mu \mathrm{l}$ in lanes 5-8, respectively) were subjected to SDS-PAGE and silver stained (Danbolt et al., 1990). The optical densities of the GLT- 1 bands were used as a standard to determine the protein concentration of the EAAC1 sample.

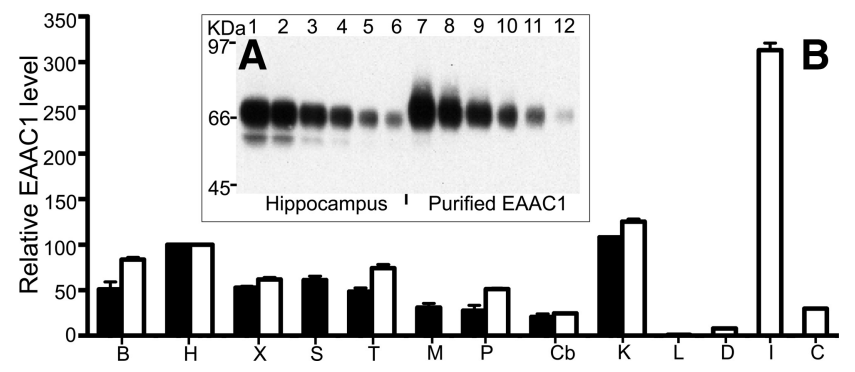

Figure 3. Quantification of EAAC1 protein and mRNA. $\boldsymbol{A}$, Immunoblot of hippocampus and purified EAAC1 (two different preparations were used as standards; only one of the preparations is shown here: $2.7,1.35,0.9,0.45,0.3$, and $0.15 \mathrm{ng}$ of EAAC 1 in lanes $7-12$, respectively). The concentration of EAAC1 in hippocampus was measured by comparing the immunoreactivities of the tissue proteins $(13.5,9,4.5,3,1.5$, and $1 \mu \mathrm{g}$ of protein in lanes $1-6$, respectively) with that of known amounts of the pure EAAC1 protein. $B$, Quantitative distribution of EAAC1 protein (solid bars) and mRNA (open bars) in different regions of rat brain. Rat EAAC1 protein levels relative to hippocampus were determined by immunoblotting using $2.5 \mu \mathrm{g}$ protein/lane and $0.3 \mu \mathrm{g} / \mathrm{ml}$ anti-C491 (Ab\#555). Bound antibodies were detected by chemiluminescence. The bands were located with exposure to $x$-ray film, and the different staining intensities on the film were analyzed with ImageJ (see Materials and Methods). The results represent mean \pm SEM of three sets of immunoblots (from three different Wistar rats aged 9-12 weeks). The values obtained from the region with highest immunoreactivity (hippocampus) were arbitrarily defined as $100 \%$, and the values from the other regions were expressed as percentage of this highest value. The EAAC1 mRNA levels in mouse tissues (12 weeks of age) were measured using TaqMan probe Mm00436590_m1 and expressed relative to the levels in hippocampus. Note that the highest levels of EAAC1 mRNA were in the intestine, kidney, and hippocampus. Abbreviations: $B$, Olfactory bulb; $H$, hippocampus; $X$, neocortex; $S$, corpus striatum; $T$, thalamus/ hypothalamus; M, mesencephalon; P, pons; $C$, cerebellum; K, kidney; L, liver; D, duodenum; I, ileum; C, colon.

were performed as described previously (Danbolt et al., 1998). Fluorescence labeling and confocal microscopy were performed as previously (Holmseth et al., 2005), while postembedding immunogold immunocytochemistry was performed according to the study by Furness et al. (2008). The sections were $40 \mu \mathrm{m}$ thick.

\section{Estimation of neuronal surface density}

This was done in the stratum radiatum of hippocampus (subfield CA1) $\sim 4 \mathrm{~mm}$ from the temporal pole using the same material as we have 
Table 3. Tissue concentrations of glutamate transporters in the hippocampus (stratum radiatum, CA1) of young adult Wistar rats

\begin{tabular}{|c|c|c|c|c|c|c|c|}
\hline & $\begin{array}{l}\text { Milligrams per } \\
\text { gram tissue } \\
\text { (mg/g tissue) }\end{array}$ & $\begin{array}{l}\text { Micromolar } \\
\text { concentration ( } \mu \mathrm{M})\end{array}$ & $\begin{array}{l}\text { Molecules per } \\
\text { cubic micrometer } \\
\left(\text { molecules } / \mu \mathrm{m}^{3} \text { ) }\right.\end{array}$ & $\begin{array}{l}\text { Square micrometers } \\
\text { per cubic micrometer } \\
\left(\mu \mathrm{m}^{2} / \mu \mathrm{m}^{3}\right)\end{array}$ & Location & $\begin{array}{l}\text { Percentage at the } \\
\text { surface }(\%)\end{array}$ & $\begin{array}{l}\text { Molecules per } \\
\text { square micrometer } \\
\text { (molecules } / \mu \mathrm{m}^{2} \text { ) }\end{array}$ \\
\hline GLAST $^{a}$ & 0.32 & 5.3 & 3200 & 1.4 & Astroglia & $\sim 100$ & 2300 \\
\hline $\mathrm{GLT}-1^{a}$ & 1.3 & 21 & 12,000 & 1.4 & $\begin{array}{l}\text { Astroglia }^{b} \\
\text { Terminals }\end{array}$ & $\begin{array}{r}\sim 100 \\
\sim 10\end{array}$ & $\begin{array}{r}7500^{b} \\
750\end{array}$ \\
\hline EAAC1 & 0.013 & 0.22 & 130 & 1.5 & Dendrites & $0-100$ & $0-90^{c}$ \\
\hline
\end{tabular}

The above data provide an indication of the average transporter densities, but expression levels are subject to regulation. Furthermore, EAAC1 is to a large extent present intracellularly in the brain (Figs. 7, 8), while most GLT-1 and GLAST

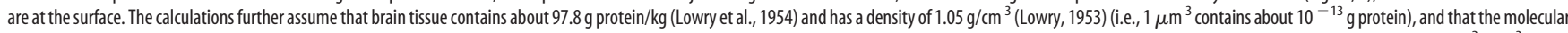
masses of the polypeptide parts of rat EAAT1 (Storck et al., 1992), EAAT2 (Pines et al., 1992), and EAAC1 (Kanai and Hediger, 1992) are 60, 62 , and $58 \mathrm{kDa}$, respectively. The total plasma membrane density was about $14 \mu \mathrm{m}^{2} / \mu \mathrm{m}^{3}$. Axons represents $\sim 70 \%$ of this, while astroglia, boutons, and dendrites, including spines, represent $\sim 10 \%$ each (Furness et al., 2008).

${ }^{a}$ Data are from the study by Lehre and Danbolt (1998).

${ }^{b}$ It is now clear that $\sim 10 \%$ of the EAAT2 is also present in synaptic terminals (Furness et al, 2008), implying that the number 8500 given by Lehre and Danbolt (1998) is slightly too high.

'A range is given because it is unclear how much is present in the plasma membrane.

previously used for measuring the glial surface density (Lehre and Danbolt, 1998). Tissue components were identified according to the studies by Peters et al. (1991) and Palay and Chan-Palay (1974). Photographs from serial sections were obtained because it is not possible to identify all the cellular processes in a single picture, and because this study required identification of all cellular processes to obtain a measure for the total cell surface. The lengths of all identified dendritic (including spines) and astroglial cell membranes, and the area of the analyzed images (104 $\mu \mathrm{m}^{2}$ ), were measured by a computer program from Science Linker AS. Surface areas of dendrites and astroglia were calculated by multiplying the membrane lengths per image area by $4 / \pi$ (Weibel, 1979).

\section{Electrophysiology}

Slice preparation. Hippocampal slices were prepared from 12- to 17-dold Sprague Dawley rats or mice, in accordance with a protocol approved by the Animal Care and Use Committee at The Johns Hopkins University. Animals were anesthetized with halothane and decapitated, the hippocampi were dissected free, mounted in agar blocks, cut in $400-\mu \mathrm{m}-$ thick transverse sections using a vibratome (VT1000S; Leica), in oxygenated ice-cold artificial CSF (ACSF) containing the following (in mM): 119 $\mathrm{NaCl}, 2.5 \mathrm{KCl}, 2.5 \mathrm{CaCl}_{2}, 1.3 \mathrm{MgCl}_{2}, 1 \mathrm{NaH} 2 \mathrm{PO}_{4}, 26.2 \mathrm{NaHCO}_{3}$, and 11 $\mathrm{D}$-glucose. Slices were allowed to recover on a gauze net submerged in ACSF at $37^{\circ} \mathrm{C}$ for $30 \mathrm{~min}$ and kept at room temperature thereafter. For cerebellar slices, $250-\mu \mathrm{m}$-thick parasagittal sections were prepared.

Whole-cell recording. Individual brain slices were placed in a chamber mounted on an upright microscope (Zeiss; Axioskop FS2) and continuously superfused with oxygenated ACSF. Individual cells (astrocytes, CA1 pyramidal neurons, or Purkinje neurons) were visualized through a $40 \times$ water-immersion objective (Olympus LUMPlanFL; NA, 0.8) using infrared-Nomarski optics and a CCD camera (Sony XC-73). Recording electrodes were pulled from glass capillary tubing and had a combined resistance of 1.5-3.0 M $\Omega$ when filled with the internal solution. For astrocytes, the internal solution contained the following (in $\mathrm{mM}$ ): 120 $\mathrm{KCH}_{3} \mathrm{O}_{3} \mathrm{~S}$ (KMeS), 10 EGTA, 20 HEPES, $1 \mathrm{MgCl}_{2}, 2 \mathrm{Na}_{2} \mathrm{ATP}, 0.2$ $\mathrm{NaGTP}$; the $\mathrm{pH}$ was 7.3. Currents recorded in this condition reflect the movement of charges directly coupled to glutamate translocation ("stoichiometric current") (Wadiche et al., 1995; Bergles et al., 2002). To increase the sensitivity of detection, we recorded transporter-associated anion currents from CA1 pyramidal neurons and Purkinje neurons using an internal solution containing the following (in mM): $100 \mathrm{CsNO}_{3}, 20$ TEA-Cl, 10 EGTA, 20 HEPES, $1 \mathrm{MgCl}_{2}$, 1 QX-314, 2 Na2ATP, 0.2 $\mathrm{NaGTP}$; the $\mathrm{pH}$ was 7.3. In this condition, responses represent both the stoichiometric current and the anion-associated transporter current. With these solutions, the series resistance during recordings was $<10$ $\mathrm{M} \Omega$ and was left uncompensated. Unless stated otherwise, holding potentials have not been corrected for the junction potential. Whole-cell currents were amplified using an Axon Multiclamp 700A (Molecular Devices), filtered at $2-5 \mathrm{kHz}$, and sampled at $10-20 \mathrm{kHz}$.

Solution application. Caged compounds were dissolved in HEPESbuffered saline (HEPES ACSF) containing the following (in $\mathrm{mM}$ ): 137 $\mathrm{NaCl}, 2.5 \mathrm{KCl}, 2.5 \mathrm{CaCl}_{2}, 1.3 \mathrm{MgCl}_{2}, 20 \mathrm{HEPES}$; the $\mathrm{pH}$ was 7.3. Solutions containing caged compounds were applied to the slice using a wide bore (tip diameter, $50-100 \mu \mathrm{m}$ ) pipette connected to a manifold fed by four
$10 \mathrm{ml}$ reservoirs. Solutions were switched by alternately opening and closing valves attached to each reservoir. Antagonists were used to block voltage-gated $\mathrm{Na}^{+}$channels [tetrodotoxin (TTX), $1 \mu \mathrm{M}$ ], AMPA/kainate receptors [2,3-dioxo-6-nitro-1,2,3,4-tetrahydrobenzo[f]quinoxaline-7sulfonamide disodium salt (NBQX), $10 \mu \mathrm{M}]$, NMDA receptors [(RS)-3(2-carboxypiperazin-4-yl)-propyl-1-phosphonic acid ( $R, S$-CPP), 10 $\mu \mathrm{M}$; and $(5 R, 10 S)-(+)-5$-methyl-10,11-dihydro-5H-dibenzo $[a, d]$ cyclohepten-5,10-imine hydrogen maleate (MK-801), $50 \mu \mathrm{M}$, and $\mathrm{GABA}_{\mathrm{A}}$ receptors [6-imino-3-(4-methoxyphenyl)-1 $(6 H)$-pyridazinebutanoic acid dihydrobromide (SR-95531), $5 \mu \mathrm{M}$ ]. In some experiments, group I mGluRs were blocked with LY367385 [( S)-(+)- $\alpha$-amino-4-carboxy-2-methylbenzeneacetic acid] (100 $\mu \mathrm{M})$. Glutamate transporters were inhibited using DLthreo- $\beta$-benzyloxyaspartic acid (TBOA) $(100-200 \mu \mathrm{M})$.

Photolysis. UV light (333.6-363.8 nm) was delivered to the sample by coupling the output of an argon ion laser (Stabilite 2017-AR; Spectra Physics) to a multimode quartz fiber optic cable (OZ Optics Ltd.). The output of the fiber optic was collimated using a quartz lens, projected through the fluorescence port of a Zeiss Axioskop FS2 microscope, and focused to a $\sim 50 \mu \mathrm{m}$ spot using a $40 \times$ water-immersion objective (Olympus LUMPlanFl). 4-Methoxy-7-nitroindolinyl-D-aspartate (MNI-D-aspartate) was applied to cells locally through a wide bore pipette, and photolysis was achieved by brief $(\sim 1 \mathrm{~ms})$ exposure to UV light, as described previously (Huang et al., 2005).

\section{Preparation of hippocampal slices from adult rat brains}

Hippocampal slices were prepared and incubated with D-aspartate essentially as described previously (Furness et al., 2008). Briefly, fresh rat hippocampal slices were incubated in Krebs' phosphate solution $(140 \mathrm{~mm} \mathrm{NaCl}$, $5 \mathrm{~mm} \mathrm{KCl}, 1.2 \mathrm{~mm} \mathrm{CaCl}_{2}, 1.2 \mathrm{~mm} \mathrm{MgSO}_{4}, 10 \mathrm{~mm}$ glucose, and $15 \mathrm{~mm}$ sodium phosphate buffer, $\mathrm{pH} 7.4$ ) with 1-50 $\mu \mathrm{M}$ D-aspartate. Negative controls were treated as above, but incubated either in the absence of D-aspartate or with the addition of $1 \mathrm{~mm}$ L-glutamate. Following incubation, slices were fixed using $1 \%$ formaldehyde and $2.5 \%$ glutaraldehyde in $0.1 \mathrm{M}$ sodium phosphate buffer, embedded by freeze substitution (Dehnes et al., 1998), and processed for immunogold transmission electron microscopy.

\section{Reconstitution of glutamate transporters into proteoliposomes}

This was done as previously described (Danbolt et al., 1990). Briefly, crude mice brains were homogenized in 10-20 vol of ice-cold water with $5 \mathrm{~mm}$ EDTA and $1 \mathrm{~mm}$ PMSF. After centrifugation $(39,000 \times g ; 20 \mathrm{~min}$; $4^{\circ} \mathrm{C}$ ), the pellet was solubilized and centrifuged as above. The supernatant was mixed with a phospholipid cholate salt mixture, incubated on ice, and gel filtered (Trotti et al., 1995) to remove detergent and sodium ions equilibrated with the desired internal medium.

\section{RNA isolation, cDNA synthesis, and TaqMan assays}

This was done as described previously (Lehre et al., 2011). Pieces of tissue (5-15 mg) were collected and immediately protected in RNAlater (Ambion/Applied Biosystems), before homogenization and RNA extraction using RNeasy (QIAGEN). The RNA concentration was quantified by using NanoDrop UV spectrometry (NanoDrop Technologies). Two micrograms of RNA were converted into cDNA by using High Capacity cDNA Archive Kit (Applied Biosystems). EAAC1 mRNA expression was 

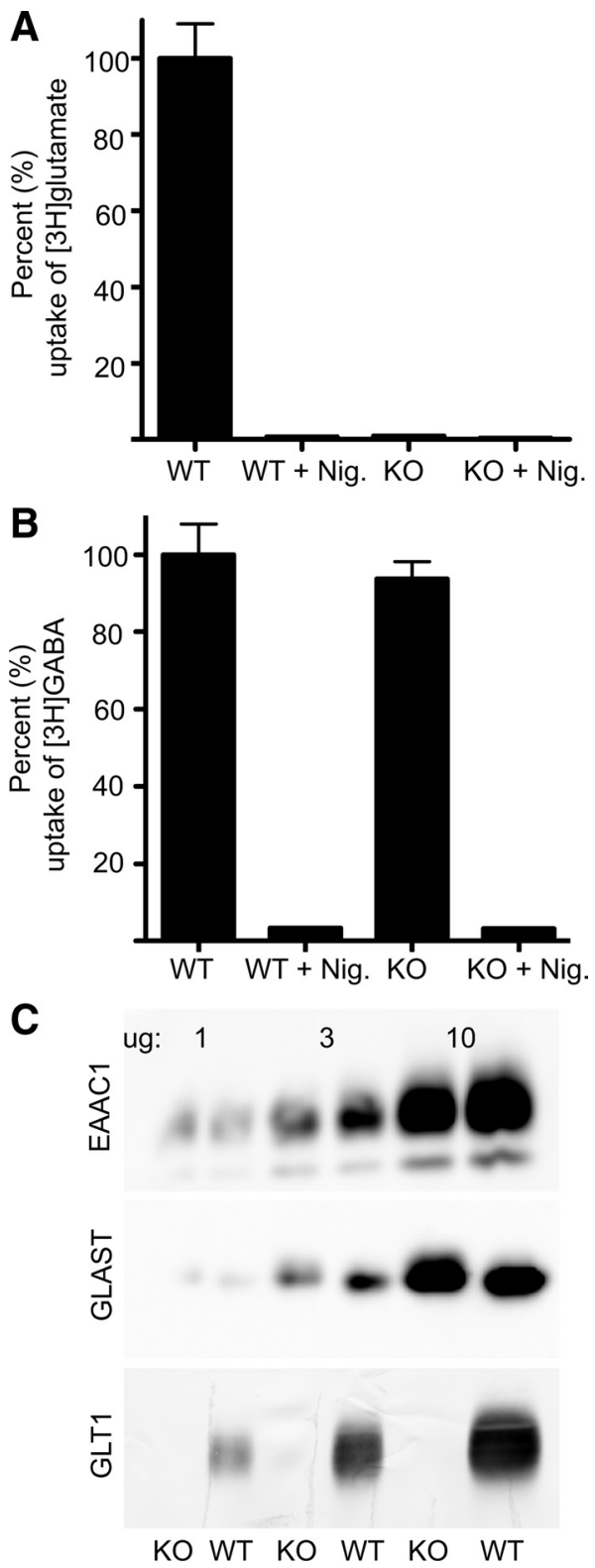

Figure 4. Glutamate uptake activity remaining when GLT-1 is knocked out. $A, \mathrm{~L}-\left[{ }^{3} \mathrm{H}\right] \mathrm{Glutamate}$ uptake in proteoliposomes prepared from forebrains from 2-week-old wild-type and GLT-1 knock-out mice. Note that the uptake in proteoliposomes prepared from GLT-1 knock-out tissue is negligible compared with those prepared from wild-type tissue. The uptake depends on the electrochemical gradients as illustrated by the fact that addition ofnigericin (Nig.) abolishes all uptake activity. B, GABA uptake activity in the same preparations of proteoliposomes. Note that liposome preparations that were unable to take up $\mathrm{L}-\left[{ }^{3} \mathrm{H}\right]$ glutamate, but accumulated $\left[{ }^{3} \mathrm{H}\right] \mathrm{GABA}$ as well as those prepared from wild-type tissue, implying that the reconstitution process has been successful. C, Immunoblots from forebrains of wild-type (WT) and GLT-1 knock-out (KO) mice show that GLT-1 was absent, while EAAC1 and GLAST were still present at normal levels. The amounts of protein in each lane were 1,3 , or $10 \mu \mathrm{g}$ as indicated. The blots were developed with antibody anti-C479 (Ab\#371; $1 \mu \mathrm{g} / \mathrm{ml}$ ) for EAAC1, anti-A522 (Ab\#314; $0.2 \mu \mathrm{g} / \mathrm{ml}$ ) for GLAST, and anti-B12 (Ab\#355; $0.1 \mu \mathrm{g} / \mathrm{ml}$ ) for GLT-1. Error bars indicate SEM.

measured using TaqMan probes (Mm00436590_m1) on a 7900HT Fast Real-Time PCR system (Applied Biosystems). The probe that was used to detect GAPDH (as control) was Mm03302249_g1.

\section{Results}

The concentration of EAAC1 protein in young adult rat hippocampus and kidney

Antibodies to EAAC1 were produced (Fig. 1) and used to immunoisolate EAAC1 protein from rat kidney. Three highly purified

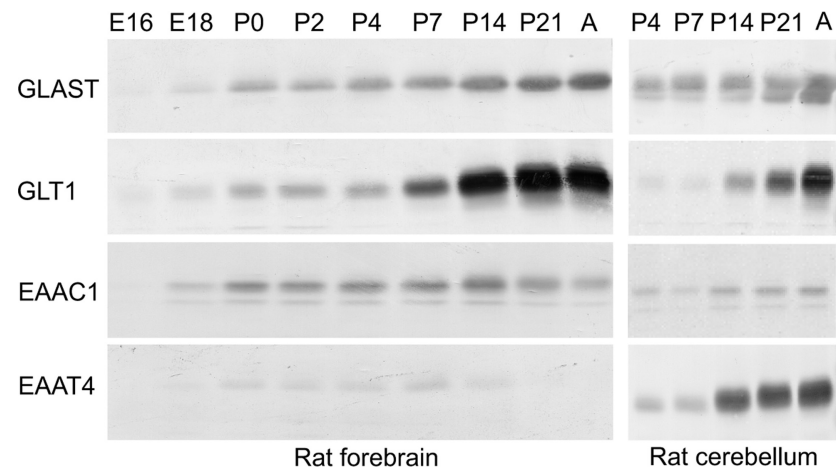

Figure 5. Changes in glutamate transporter expression during brain development. GLAST, GLT-1, EAAC1, and EAAT4 protein expression were analyzed in rat forebrain and cerebellum tissue from E16 to adult age ( 2 months). The figure represents four identical immunoblots (of the same samples) probed with antibodies to the various glutamate transporter subtypes as indicated. Note that the EAAC1 concentration in the forebrain is at its highest at P14. Similar blots were made from two other sets of animals with the same result (data not shown). Abbreviation: A, Adult. Each lane contained $20 \mu \mathrm{g}$ of protein, and the blots were developed with antibody: anti-A522 (Ab\#314; $0.2 \mu \mathrm{g} / \mathrm{ml}$ ) for GLAST and anti-B12 (Ab\#291; $0.2 \mu \mathrm{g} / \mathrm{ml}$ ) for GLT-1; anti-C491 (Ab\#237; $1 \mu \mathrm{g} / \mathrm{ml}$ ) for EAAC1 and anti-D537 (Ab\#181; $1 \mu \mathrm{g} / \mathrm{ml})$ for EAAT4.

preparations of EAAC1 protein were obtained (Fig. 2, lanes 5-8; Table 1). To circumvent the problem of partial aggregation (see Materials and Methods), the concentrations of the monomer in these preparations were determined densitometrically on silverstained gels by comparing with known amounts of pure GLT-1 protein (Fig. 2, lanes 1-4). Then, immunoreactivity of the EAAC1 monomer in the three purified preparations (Table 1) was compared with that of the EAAC1 monomers in tissue extracts (Fig. 3A, Table 2) and found to correspond to $0.10 \pm 0.011$, $0.16 \pm 0.004$, and $0.13 \pm 0.013$ mg of EAAC1 monomer, respectively (mean \pm SEM), per gram of total protein. From this, we concluded that the concentration of EAAC1 protein in young adult rat hippocampus tissue is $\sim 0.013 \pm 0.02 \mathrm{mg} / \mathrm{g}$ (tissue wet weight). For kidney whole-tissue extracts, the corresponding numbers were $0.014 \pm 0.001$ and $0.02 \pm 0.01 \mathrm{mg} / \mathrm{g}$ tissue (from two purified preparations: Table 1, numbers 1357 and 1358). In the cerebellum, the amount was found to be lower, $\sim 0.003 \pm$ $0.001 \mathrm{mg} / \mathrm{g}$ cerebellar tissue (based on number 1374). When the molecular mass of EAAC1 $(58 \mathrm{kDa})$ is taken into account, it follows that the EAAC1 concentration in hippocampal neuropil is $1.3 \times 10^{17}$ molecules/L tissue or $0.22 \mu \mathrm{M}$, corresponding to $\sim 130$ EAAC1 molecules $/ \mu \mathrm{m}^{3}$ (Table 3 ).

\section{Glutamate uptake in GLT-1-deficient mice}

The above data suggest that EAAC1 is expressed at levels that are $\sim 100$ times lower than those of GLT-1 (Table 3). This is in agreement with the low uptake activities observed in synaptosome preparations from GLT-1 deficient mice (Tanaka et al., 1997). However, we have recently shown that synaptosome preparations mostly detect GLT-1 catalyzed glutamate uptake into terminals (Furness et al., 2008). The possibility therefore existed that EAAC1 expressed in other compartments could have been underestimated. To obtain an estimate for the total uptake activity of all transporters in the tissue independently of whether they are present in cellular compartments that do not reseal after homogenization, we solubilized the tissue in cholate and reconstituted the transporters in artificial cell membranes (liposomes) containing internal potassium as we have done previously (Danbolt et al., 1990). These liposome preparations did not give any indications that EAAC1 is a major contributor to uptake, because the gluta- 
mate uptake activity in liposomes prepared from GLT-1 knock-out tissue (forebrain) was very low ( $\sim 2 \%$ of wild type) compared with that of liposomes prepared from wild-type tissue (Fig. 4A). GABA uptake activity was used as a positive control and was found to be similar in liposomes made from wild-type and GLT-1 knock-out mice (Fig. 4B). The ionophore nigericin abolished all uptake activity (of both glutamate and GABA) and served as a negative control, as it collapses transmembrane ion gradients. Furthermore, immunoblots showed that GLT-1-deficient mice have normal levels of EAAC1 (Fig. 4C). Although EAAT4 was readily detected in the cerebellum, detection of the tiny amounts of EAAT4 present in the forebrain requires other methods (Dehnes et al., 1998).

\section{Changes in EAAC1 concentrations during development}

Rat brain tissue from E16 to adult was immunoblotted with antibodies to four different glutamate transporter subtypes. In contrast to the dramatic upregulation of GLAST and GLT-1 in the hippocampus with age (Furuta et al., 1997; Ullensvang et al., 1997), which parallels synaptogenesis and synaptic refinement, only modest changes in the expression of EAAC1 were observed with age (Fig. 5). EAAC1 levels increased slightly after birth and peaked at P14, before decreasing to approximately one-half over the next 6 weeks. These results suggest that there is a transient increase in demand for EAAC1 activity during early postnatal life.

\section{Regional distribution of EAAC1 protein and $\mathrm{mRNA}$ in the young adult rat}

After having determined the concentration of EAAC1 protein in hippocampus, other brain regions were compared with the hippocampus by immunoblotting

(Fig. 3B, solid columns). The concentrations in the striatum, neocortex, olfactory bulb, and thalamus/hypothalamus (in decreasing order) were $\sim 50 \%$ lower than in the hippocampus. The levels in the cerebellum, mesencephalon, and pons/medulla oblongata (in decreasing order) were at approximately one-third to one-quarter of the amount in the hippocampus, in agreement with the quantification (see above). These data are in reasonable agreement with the mRNA levels (Fig. 3B, open columns) and with the regional labeling intensity seen on tissue sections (Fig. 6 ), when the latter were processed in the presence of Triton X-100 to maximize penetration of the reagents (Lehre et al., 1995; Danbolt et al., 1998).

\section{Specificity of EAAC1 antibodies in fixed tissue}

Because intact fixed tissue might contain epitopes that are not present on immunoblots and vice versa (Holmseth et al., 2012), the antibodies were also tested on sections of wild-type and
Anti-C479

Ab\#359
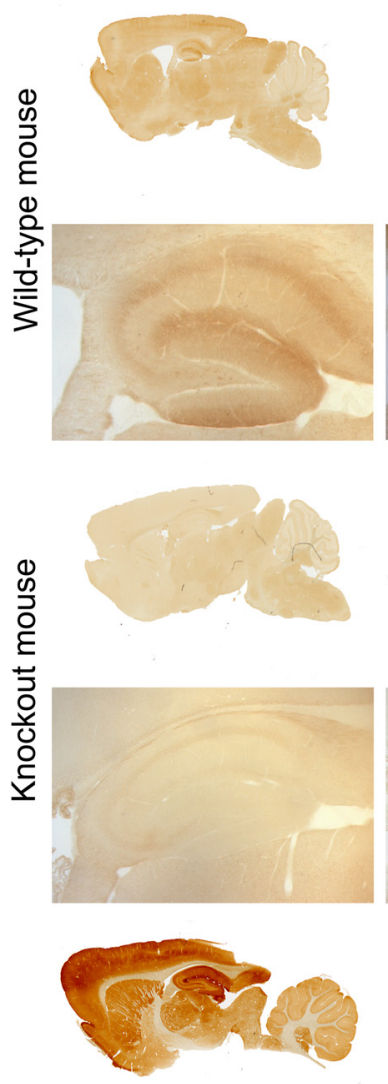

শัণ

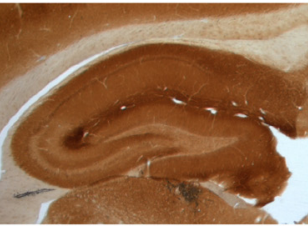

Anti-C491

Ab\#371
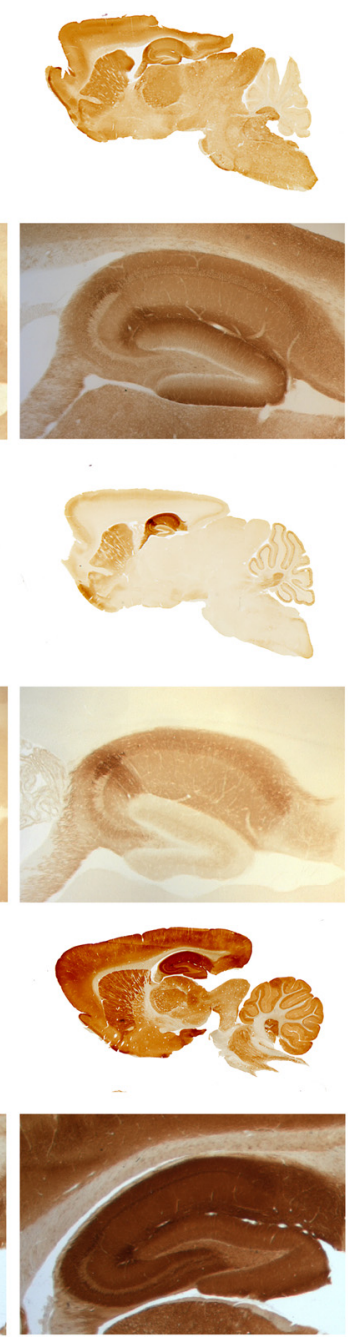

Anti-C510

Ab\#565
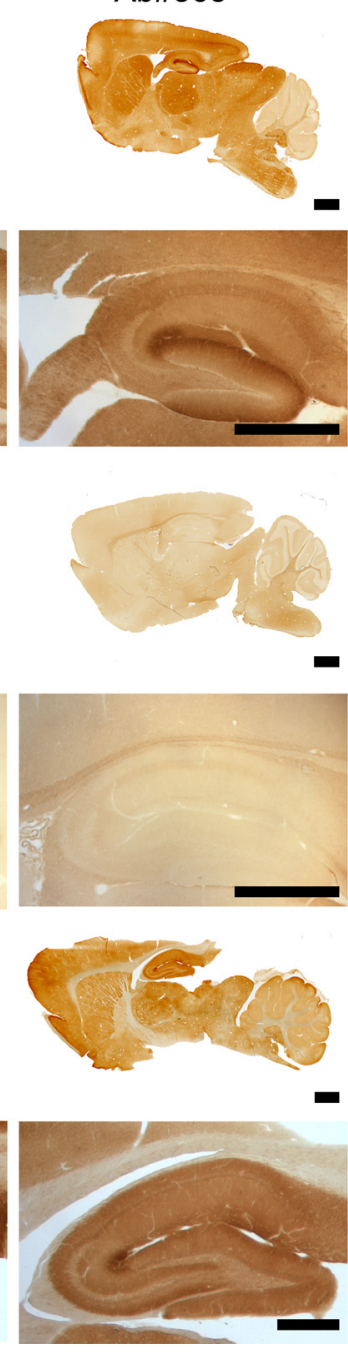

Figure 6. Diaminobenzidine-peroxidase labeling of brain sections from rat and mice (wild-type and EAAC1 deficient) with three different EAAC1 antibodies. High magnifications of hippocampus are shown below the overview pictures. Note that anti-C510 gave e best contrast between the wild-type and the knock-out tissue. Anti-C479 produced only weak labeling in the mouse sections

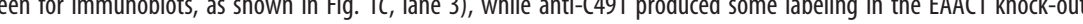
X-100 (0.5\%) was included in the solutions. Rat and mouse tissue perfusion fixed with $4 \%$ formaldehyde and $0.1 \%$ glutaraldehyde in $0.1 \mathrm{~m}$ sodium phosphate buffer. Rats were 14 weeks of age, and mice were 4 weeks of age. Scale bar, $2 \mathrm{~mm}$.

EAAC1-knock-out mice (Fig. 6). As shown previously (Holmseth et al., 2005, 2012), the anti-C491 antibodies recognize both rat and mice, while the anti-C479 antibodies produce only weak labeling of mouse sections and immunoblots (Fig. 1, compare strips labeled with anti-C479 in A, C; Fig. 6). Most brain regions in EAAC1deficient mice displayed very little labeling when compared with the same regions in the wild-type mice. However, the anti-C491 antibodies (Ab\#371) produced some labeling in EAAC1-deficient tissue (Fig. 6), although they appeared specific on immunoblots (Fig. 1) (Holmseth et al., 2012). Labeling in the knock-out mice was observed in the hippocampus CA1-3 (CA2 in particular) and in the striatum as well as in some other regions of the brain (e.g., piriform cortex). The identity of the cross-reacting molecule(s) was not determined, but it appears to have a cellular expression profile similar to EAAC1. The labeling in the EAAC1-deficient mice was only seen in neurons (somatodendritic compartment) and was thereby expressed in the same cells as those expressing EAAC1 (data not shown). 


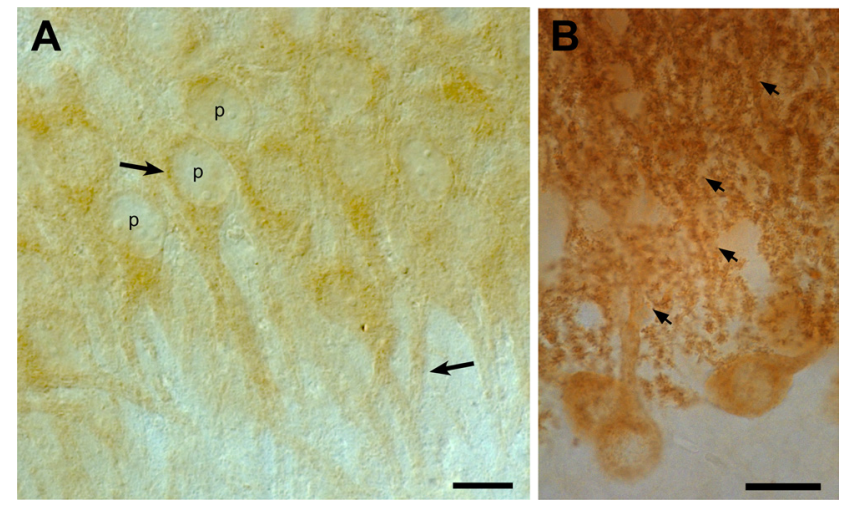

Figure 7. EAAC1 is present in neuronal somata and dendrites, but is not enriched in spines. $\boldsymbol{A}$, High magnification of hippocampus (A3 from EAAC1 wild-type mouse (4 weeks of age) labeled with anti-C510 (Ab\#565; $10 \mu \mathrm{g} / \mathrm{ml}$ ). Note that cytoplasm in neuronal somata of pyramidal cells and dendrites are labeled (arrows). Pyramidal cell nuclei (p) are unlabeled (only 3 are indicated). The tissue was perfusion fixed with $4 \%$ formaldehyde and $0.1 \%$ glutaraldehyde in $0.1 \mathrm{~m}$ sodium phosphate buffer and processed in the absence of Triton X-100. B, Cerebellum (young adult Wistar rat) labeled with anti-D537 (Ab\#181; $10 \mu \mathrm{g} / \mathrm{ml}$ ) antibodies to EAAT4 [from the same material as in the study by Dehnes et al. (1998)]. Note the huge number of intensely labeled tiny dots representing spines. The arrows point to four of them. Scale bars, $20 \mu \mathrm{m}$.

Note that the regional labeling patterns in mouse and rat obtained with the three antibodies are quite similar. As shown (Fig. 6), some differences in the hippocampus were noted, but these should not be overinterpreted as it is difficult to get all parameters identical (animal age, fixation time, postfixation time, storage, time from sectioning to labeling, as well as all of the assay conditions, such as presence or absence of Triton X-100) and EAAC1deficient rats were not available. At present, it is therefore unclear whether these differences between mouse and rat reflect actual differences in EAAC1 distribution, or arise from procedural differences.

\section{Cellular and subcellular localization of EAAC1}

Vibratome sections of perfusion-fixed rat brain were labeled with the various antibodies to EAAC1 in the absence of Triton X-100 using peroxidase as reporter. Light microscopy showed that labeling intensities varied between the various hippocampal subfields, with highest labeling observed in the dentate gyrus and the CA1 subfield. In these areas, we observed labeling of neuronal cell bodies and dendrites in both rats and wild-type mice with all of the available anti-EAAC1 antibodies (Figs. 7A, 8D). EAAC1 was found in all cells identified as neurons, including parvalbuminpositive hippocampal interneurons (Fig. 8). In contrast, no labeling of endothelium was observed. Furthermore, the choroid plexus and the lining of the ventricles also were unlabeled, indicating that EAAC1 was not expressed by ependymal cells or tanycytes.

We also did not detect EAAC1 in astrocytes in the adult or juvenile neocortex and hippocampus. Double labeling of sections with EAAC1 in combination with GLT-1 (Fig. 9A), glial fibrillary acidic protein (GFAP) (Fig. 9B), glutamine synthetase (GS) (Fig. $9 C-G$ ), or GLAST (Fig. 9H) did not reveal any colocalization between EAAC1 and astrocytic markers. Two different GLT-1 antibodies were used as a positive control for colocalization (Fig. 9I). In the corpus callosum, there also was no colocalization of EAAC1 with markers for mature oligodendrocytes (MBP; CNPase), and the EAAC1-immunoreactive cells were scattered rather than organized in string-like arrays typical of oligodendrocytes (Fig. 10). EAAC1 immunoreactivity also did
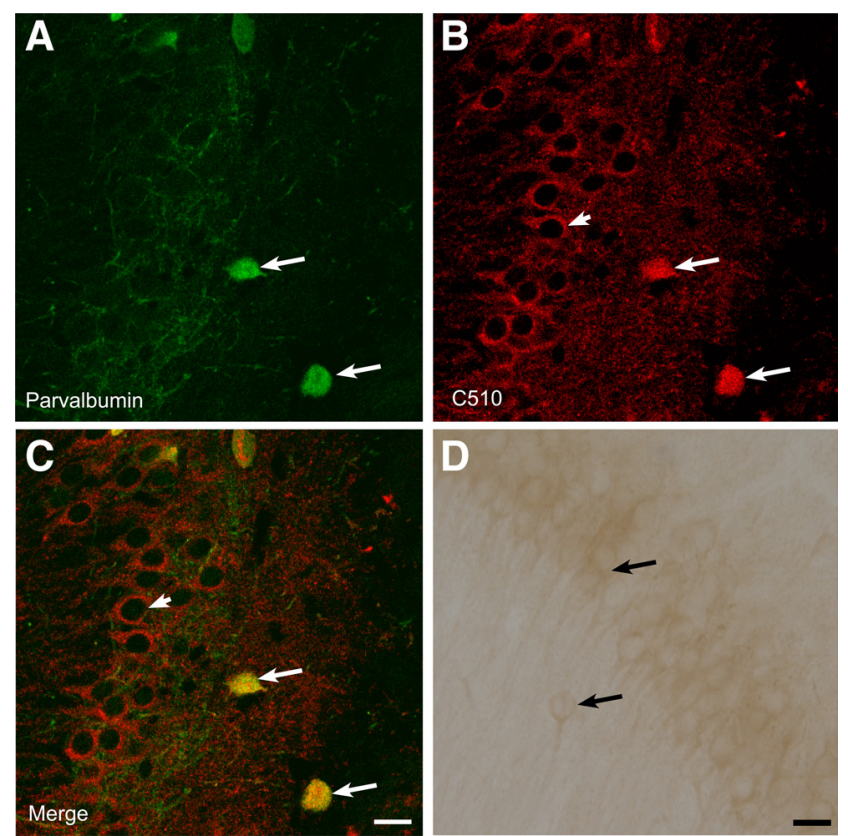

Figure 8. Hippocampal GABAergic interneurons expressing parvalbumin also express EAAC1. $\boldsymbol{A}-\boldsymbol{C}$, Anti-parvalbumin (1:500) (A, green), anti-EAAC1 (anti-C510; Ab\#565; $10 \mu \mathrm{g} / \mathrm{ml}$ ) $(\boldsymbol{B}$, red), and a merged picture of the two (C).D, Anti-EAAC1 (anti-C510; Ab\#565; $10 \mu \mathrm{g} / \mathrm{ml}$ ) developed with the diaminobenzidine-peroxidase labeling system. Note that both EACC1 and parvalbumin are expressed in cell bodies in stratum pyramidale (arrowhead) and stratum radiatum (arrows). The tissue in $\boldsymbol{A}-\boldsymbol{C}$ is from mouse, 3 weeks of age, perfusion fixed with $4 \%$ formaldehyde in $0.1 \mathrm{~m} \mathrm{NaPi}$. $\boldsymbol{D}$ is from a 3-week-old mouse perfusion-fixed with $4 \%$ formaldehyde and $0.05 \%$ glutaraldehyde in $0.1 \mathrm{~m} \mathrm{NaPi}$. Scale bars, $20 \mu \mathrm{m}$.

not colocalize with NG2, indicating that this transporter is not expressed by oligodendrocyte precursor cells (NG2 cells) or pericytes. This is in agreement with a previous report (Berger and Hediger, 1998), which suggested that EAAC1immunoreactive cells in the corpus callosum represent interneurons.

In contrast to the strong immunoreactivity observed in the soma and dendrites of neurons, there was no detectable colocalization between EAAC1 and markers for nerve terminals in the neocortex, hippocampus, or cerebellar nuclei. As shown (Fig. 11), EAAC1 antibodies did not label the structures that were labeled with antibodies to synaptophysin, GAD, and VGLUT1. Moreover, it is clear from these sections that EAAC1 labeling was largely intracellular in the brain. This is in contrast to the kidney, where EAAC1 is concentrated at the cell surface, particularly in the brush border of proximal tubules (Fig. 12).

The EAAC1 immunoreactivity observed electron microscopically (Fig. 13) was very low, in agreement with the labeling intensity observed by light microscopy (Fig. 7A). By contrast, the very strong labeling that we have previously observed with antibodies to GLT-1 and GLAST (Danbolt et al., 1992; Levy et al., 1993; Chaudhry et al., 1995; Lehre et al., 1995) and to EAAT4 in the cerebellum (Dehnes et al., 1998) is not only due to good antibodies and tissue processing, but also due to the fact that these proteins are expressed at very high levels (Lehre and Danbolt, 1998). With GLT-1 antibodies and gold-labeled secondary antibodies, we observed, on average, $\sim 10$ gold particles/ $\mu \mathrm{m}$ membrane length, and background labeling was minimal (Chaudhry et al., 1995; Furness et al., 2008). Considering that EAAC1 is expressed at levels 2 orders of magnitude lower, it is not surprising that the immunogold labeling was similar to the background level observed in the EAAC1-knock-out tissue. Thus, the 

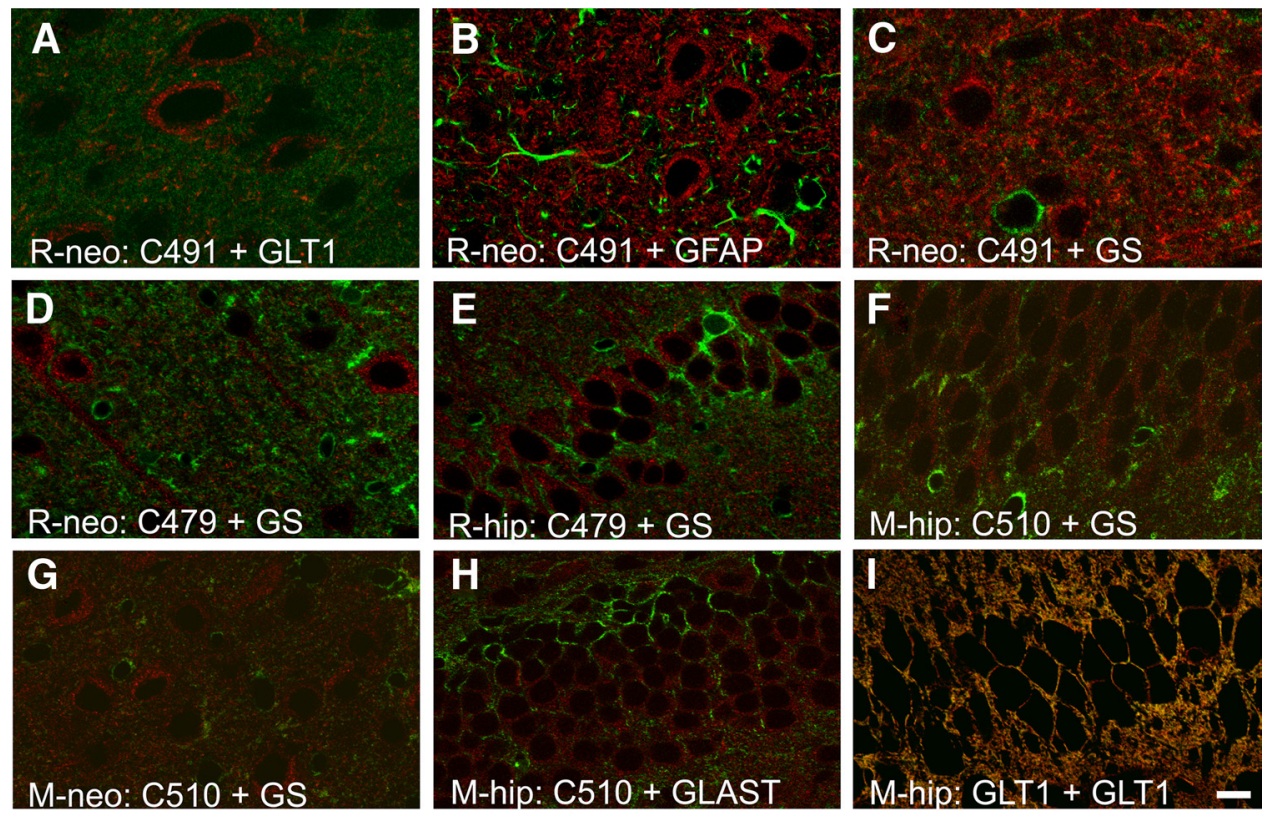

Figure 9. Double labeling with three different EAAC1 antibodies (red) and different astrocyte markers (green). In $A-C$, anti-C491 (Ab\#371; $0.5 \mu g / m l)$ is used together with the following markers: GLT-1 (A; 1:500), GFAP ( $\boldsymbol{B} ; 1: 500)$, and GS $(\boldsymbol{C} ; 1: 500)$ in rat neocortex. In $\boldsymbol{D}$ and $\boldsymbol{E}$, anti-C479 (Ab\#359; $3 \mu \mathrm{g} / \mathrm{ml})$ is used together with glutamine synthetase in rat neocortex (D) and in rat hippocampus $C A 1(\boldsymbol{E})$. In $\boldsymbol{F}-\boldsymbol{H}$, anti-C510 (Ab\#565;30 $\mathrm{gg} / \mathrm{ml})$ is used together with glutamine synthetase $(\boldsymbol{F}, \boldsymbol{G})$ or anti-GLAST (Banner et al., 2002) $(1: 500)(\boldsymbol{H})$ as indicated. $\boldsymbol{F}$ and $\boldsymbol{H}$ are from mouse hippocampus CA1, while $\mathbf{G}$ is from mouse neocortex. Double labeling with mouse anti-GLT-1 (9C4; Ab\#531; 1:30) and rabbit anti-GLT-1 (Ab\#360; $0.5 \mu \mathrm{g} / \mathrm{ml})$ is a positive control for colocalization $(I)$. Note that there is no significant colocalization between EAAC1 and the various astroglial markers. Rat and mouse tissue was perfusion fixed with $4 \%$ formaldehyde in $0.1 \mathrm{~m}$ sodium phosphate buffer. Rats were 9 weeks of age, and mice were 3 weeks of age. Abbreviations: M-hip, Mouse hippocampus; M-neo, mouse neocortex; R-hip, rat hippocampus; R-neo, rat neocortex. Scale bars, $10 \mu \mathrm{m}$.
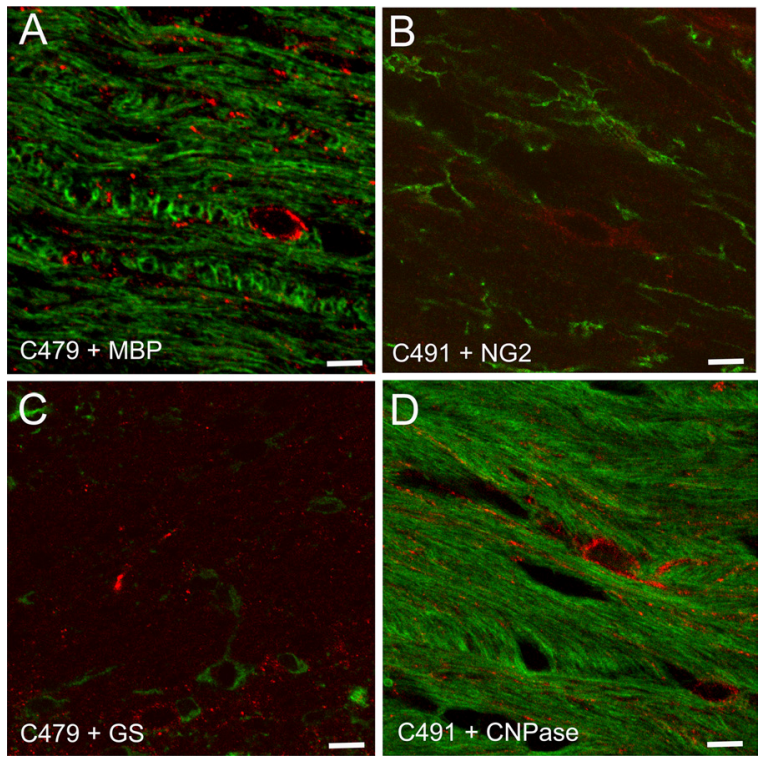

Figure 10. Double labeling with various EAAC1 antibodies (red) and markers for oligodendrocytes (green) in corpus callosum from adult mouse. In $A$ and $C$, anti-C479 (Ab\#359; $3 \mu \mathrm{g} / \mathrm{ml}$ ) is used together with the anti-MBP $(\boldsymbol{A} ; 1: 500)$ and anti-GS $(\boldsymbol{C} ; 1: 500)$. In $\boldsymbol{B}$ and $\boldsymbol{D}$, anti-C491 (Ab\#371; $0.5 \mu \mathrm{g} / \mathrm{ml})$ is used together with anti-NG2 (B; $1: 500)$ and anti-CNPase $(\boldsymbol{D} ; 1: 500)$. Note that there is no detectable colocalization with any of the glial markers. Scale bar, $10 \mu \mathrm{m}$.

quantification of EAAC1 protein (see above) and the immunocytochemical labeling intensities are in agreement with each other.

EAAC1 labeling was detected intracellularly in perikaria and dendrites (Fig. 13). No labeling was observed in structures clearly identified as terminals, axons, or glial cell processes. Although there was some labeling of the outer membranes of mitochondria, this may represent nonspecific binding, because mitochondria have been shown not to contain EAAC1 (Holmseth et al., 2006). Together, these studies show that EAAC1 is predominantly intracellular, but is expressed at such low levels that it is close to the detection limit using immunolabeling approaches suitable for electron microscopy.

The number of EAAC1 molecules per square micrometer of plasma membrane

As shown previously (Furness et al., 2008), the most important factor to consider when calculating surface densities is whether or not a protein is expressed in axons and terminals because these structures account for approximately three-quarters of the total plasma membranes in stratum radiatum of hippocampus CA1. The dendritic surface area in this area is $1.5 \mu \mathrm{m}^{2} / \mu \mathrm{m}^{3}$, similar to the surface area of spines in the molecular layer of the cerebellum $\left(1.1 \mu \mathrm{m}^{2} / \mu \mathrm{m}^{3}\right)$ (Dehnes et al., 1998). The astroglial surface area, which was included as a control, is $1.4 \mu \mathrm{m}^{2} / \mu \mathrm{m}^{3}$, and thus identical to our previous analysis using a different stereological method (Lehre and Danbolt, 1998). Given the measured EAAC1 concentrations (Tables 2, 3), the mean EAAC1 density is $\sim 90$ molecules $/ \mu \mathrm{m}^{2}$ dendritic membrane, provided all EAAC1 is inserted into the membrane. However, as most of the EAAC1 is located intracellularly, it is likely that only a small fraction of these transporters are exposed to the extracellular environment. The above calculations assume that EAAC1 is evenly distributed. Note (Fig. $7 A$ ) that EAAC1 is present in spines, but not enriched there. In fact, spines are hard to see light microscopically after EAAC1 labeling in sharp contrast to EAAT4 labeling (Fig. 7B) [Dehnes et al. (1998), their Figs. 4, 6]. 

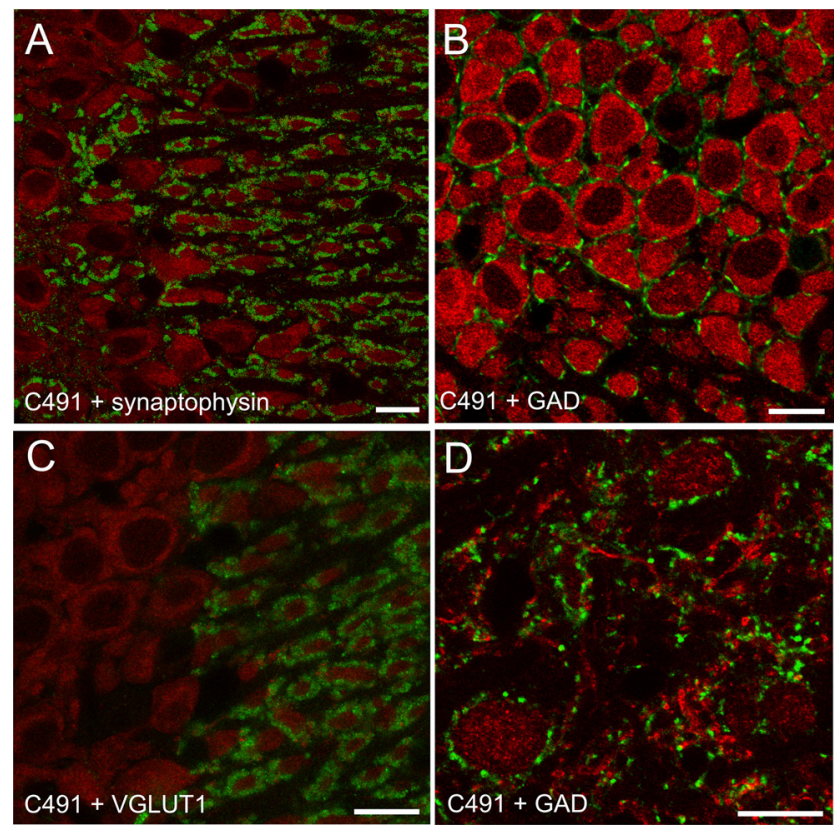

Figure 11. Double labeling with EAAC1 (red) and various markers for nerve terminals (green). $\boldsymbol{A}-\boldsymbol{D}$ show EAAC1 labeled with anti-C491 (Ab\#371; $1 \mu \mathrm{g} / \mathrm{ml})$ together with antisynaptophysin (1:1000) $(\boldsymbol{A})$, anti-GAD (1:500) $(\boldsymbol{B}, \boldsymbol{D})$, and anti-VGLUT1 (1:200). Note that there is no detectable colocalization with any of the markers for terminals. $A-C$ are from hippocampus $C A 1$, while $\boldsymbol{D}$ is from the cerebellar nuclei. Rat tissue ( 9 weeks) was perfusion fixed with $4 \%$ formaldehyde in $0.1 \mathrm{~m}$ sodium phosphate buffer. Scale bars, $20 \mu \mathrm{m}$.
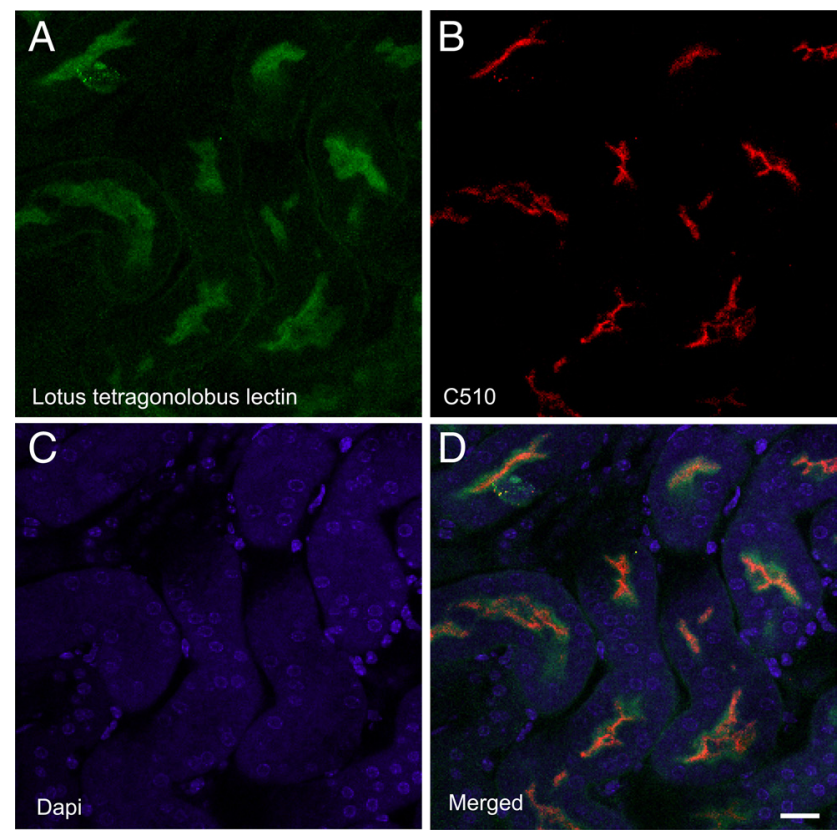

Figure 12. Double labeling with EAAC1 (red) and a marker for renal proximal tubules (L. tetragonolobus lectin; green). A shows $L$. tetragonolobus lectin (1:300), B shows EAAC1 labeled with anti-C510 (Ab\#565; $3 \mu \mathrm{g} / \mathrm{ml}), \boldsymbol{C}$ shows cell nuclei (DAPI staining), and $\boldsymbol{D}$ is a merged picture of the three channels. Note that EAAC1 is concentrated in the brush border of proximal tubules. Mouse tissue ( 12 weeks) was perfusion fixed with $4 \%$ formaldehyde and $0.1 \%$ glutaraldehyde in $0.1 \mathrm{~m}$ sodium phosphate buffer. Scale bar, $10 \mu \mathrm{m}$.

Lack of detectable glutamate transporter currents in hippocampal CA1 pyramidal neurons

To determine whether the surface density of EAAC1 in hippocampal neurons is sufficient to produce detectible transporter currents, we
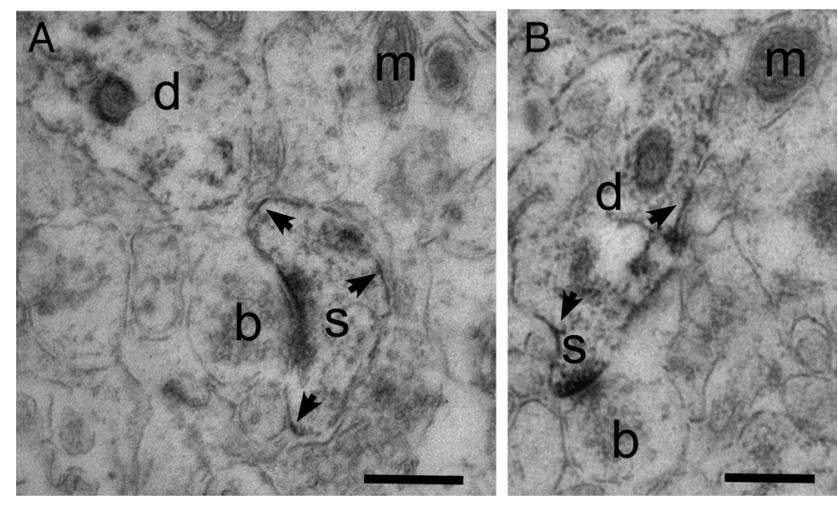

Figure 13. Electron micrographs from dentate gyrus molecular layer of wild-type mouse show EAAC1 labeling in dendrites and spines. Note that this image has been produced by labeling of Vibratome sections similar to that in Figure 7. Then parts of those sections were embedded and processed for electron microscopy. Thus, Figure 7 gives the overview and shows that the labeling is weak, while this figure shows a detail at high magnification. In agreement with the light microscopy, weak labeling is found electron microscopically in dendritic compartments (d), including spines (s). The arrowheads point at labeling at the cell membrane in spines. Note that the labeling appears more patchy than the astrocytic GLT and GLAST membrane labeling produced with the same method in our previous studies (Lehre et al., 1995). Mitochondria (m) are indicated. Boutons (b) appear unlabeled. Antibody: Anti-C510 (Ab\#565; $10 \mu \mathrm{g} /$ $\mathrm{ml}$ ). Mouse tissue (4 weeks) was perfusion fixed with $4 \%$ formaldehyde and $0.05 \%$ glutaraldehyde in $0.1 \mathrm{~m} \mathrm{sodium}$ phosphate buffer. Scale bars, $300 \mathrm{~nm}$.

made whole-cell voltage-clamp recordings from CA1 pyramidal neurons using solutions appropriate to maximize transporter current amplitude. Although photolysis of caged D-aspartate (MNI-Daspartate), a substrate of glutamate transporters, reliably elicited large inward currents in hippocampal astrocytes $(-415 \pm 67 \mathrm{pA}$; $n=6)$ (Fig. 14A) and cerebellar Purkinje neurons ( $-634 \pm 63 \mathrm{pA}$; $n=8)$ (Fig. 14B) in rat CNS tissue, which were inhibited by the glutamate transporter antagonist TBOA $(200 \mu \mathrm{M})$, only small responses were observed in hippocampal pyramidal neurons $(-9 \pm 2$ pA; $n=7$ ) (Fig. 14C1). These small currents were not sensitive to TBOA, and responses with similar kinetics were observed in both wild-type ( $-6 \pm 1 \mathrm{pA} ; n=3)$ and EAAC1-deficient mice $(-5 \pm 1$ $\mathrm{pA} ; n=5 ; p>1)$, indicating that they did not arise from cycling of EAAC1. These findings are in agreement with previous studies that found that evoked release of glutamate from Schaffer collateral fibers in rat did not elicit transporter currents in CA1 pyramidal neurons (Bergles and Jahr, 1998), providing further support for the conclusion that few functional EAAC1 transporters are present at the cell surface of these neurons.

\section{D-Aspartate uptake in nerve terminals in rat} hippocampal slices

To increase the sensitivity of detection, we attempted to visualize EAAC1 activity in spines using immunocytochemistry. D-Aspartate was chosen as a transporter substrate because this molecule is poorly metabolized in brain tissue (Davies and Johnston, 1976; Takagaki, 1978). Hippocampal slices were incubated with D-aspartate, fixed, embedded, cut, immunolabeled, and studied electron microscopically in the stratum radiatum of area CA1. D-Aspartate immunoreactivity was observed in synaptic terminals (Fig. 15) and astroglia (data not shown). Despite heavy labeling of these structures, no labeling of spines was observed (Fig. 15). Hippocampal slices incubated without D-aspartate had very little immunoreactivity, while slices incubated with D-aspartate in combination with an uptake inhibitor (Lglutamate or dihydrokainate) were weakly positive (data not shown) (Furness et al., 2008). Thus, the uptake activity in 
A
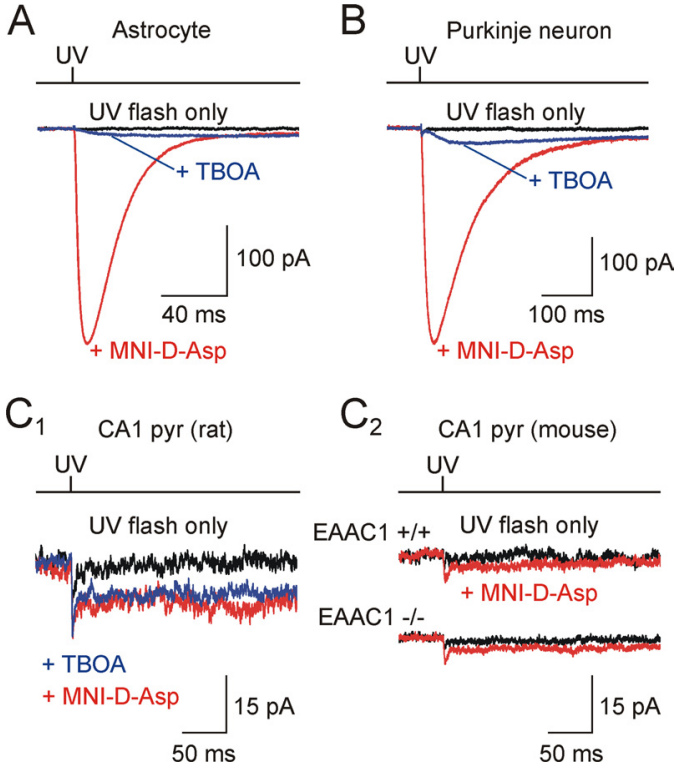

Figure 14. Glutamate transporter currents are visible in hippocampal astrocytes and cerebellar Purkinje neurons, but not hippocampal CA1 pyramidal neurons. $A$, A transient inward current was elicited in an astrocyte by a $1 \mathrm{~ms}$ flash of UV laser light. The inward current was observed only in the presence of MNI-D-aspartate (MNI-D-Asp) (125 $\mu \mathrm{M})$, and was inhibited by TBOA $(200 \mu \mathrm{m})$. The trace above shows the duration of UV exposure. Recordings were made from astrocytes located in stratum radiatum of area CA1, in the presence of TTX $(1 \mu \mathrm{M}), R, S$-CPP $(10 \mu \mathrm{m}), \mathrm{MK}-801(50 \mu \mathrm{m}), \mathrm{NBQX}(10 \mu \mathrm{M})$, and SR-95531 (5 $\mu \mathrm{M})$. Astrocytes were voltage clamped at $-80 \mathrm{mV}$ with a KMeS-based internal solution. $\boldsymbol{B}$, Glutamate transporter currents evoked in Purkinje neurons through photolysis of MNI-D-aspartate (500 $\mu \mathrm{m})$, in the absence and presence of TBOA $(200 \mu \mathrm{m})$. Cesium nitrate $\left(\mathrm{CsNO}_{3}\right)$-based internal solution. $\mathbf{C}$, Glutamate transporter currents were not observed in hippocampal CA1 pyramidal neurons. C1, A small inward current was evoked in a rat hippocampal CA1 pyramidal neuron in response to photolysis of MNI-D-aspartate (500 $\mu \mathrm{m})$. The inward current was slightly larger in the presence than in the absence of MNI-D-aspartate; however, this response was not inhibited by TBOA (200 $\mu \mathrm{M}$ ). C2, Photolysis-evoked currents from CA1 pyramidal neurons in slices from wild-type $\left(\right.$ EAAC $1^{+/+}$) and EAAC1-deficient (EAC $1^{-/-}$) mice, showing no significantly larger current in wild-type mice. Recordings were made in the presence of TTX (1 $\mu \mathrm{M}), R, S$-CPP $(10 \mu \mathrm{M})$, MK-801 (50 $\mu \mathrm{m})$, 5,7-dichlorolkynurenic acid (20-100 $\mu \mathrm{M})$, NBQX (10 $\mu \mathrm{m})$, and SR-95531 (5 $\mu \mathrm{M})$. Pyramidal neurons were voltage clamped at $-65 \mathrm{mV}$ with a potassium thiocyanatebased internal solution.

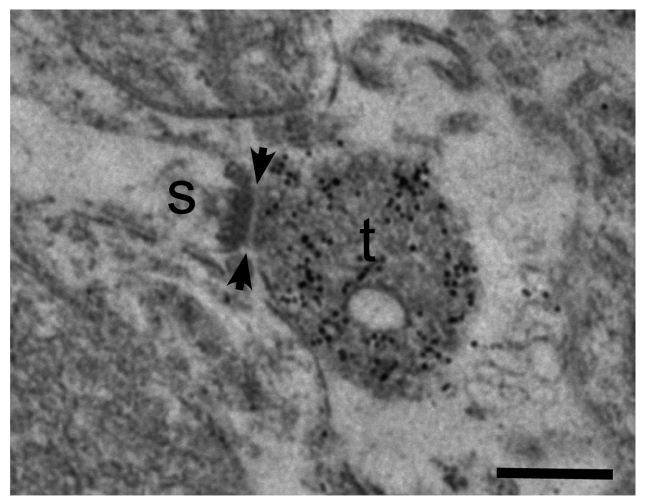

Figure 15. Glutamate uptake in spines is relatively low, as demonstrated by D-aspartate uptake and immunoreactivity. Hippocampal slices from adult rat ( 9 weeks of age) were incubated in D-aspartate (50 $\mu \mathrm{m} ; 3 \mathrm{~min}$ ), fixed (1\% formaldehyde and $2.5 \%$ glutaraldehyde), and immunogold labeled with antibodies to glutaraldehyde-fixed D-aspartate. Labeling shows accumulation of $\mathrm{D}$-aspartate in nerve terminals $(\mathrm{t})$ (there is a high number of black uniformly sized dots representing gold particles over the terminal). Glial cells (data not shown) were also heavily labeled. Dendrites and dendritic spines (s) were virtually unlabeled. Note that there are no gold particles over the spine (s). The arrowheads indicate the location of a synaptic cleft. Scale bar, $300 \mathrm{~nm}$. spines is negligible compared with that present in other synaptic compartments.

\section{Discussion}

The dynamics of extracellular glutamate in the CNS is tightly controlled by a diverse family of glutamate transporters. Distinct transporters are expressed by both glial cells and neurons; however, their relative contribution to clearance of glutamate at synapses has remained controversial. In particular, disparate conclusions have been reached regarding the roles of EAAC1. To address this, we determined the concentration and localization of $\mathrm{EAAC1}$ in the rat CNS.

\section{EAAC1 is exclusively expressed by neurons throughout the CNS}

Immunolabeling studies using antibodies validated on EAAC1 knock-out tissue revealed that EAAC1 was present in the cell bodies and dendrites of most, if not all, neurons in the forebrain, in both glutamatergic and GABAergic neurons. This conclusion is in agreement with all other reports that have analyzed EAAC1 distribution (for review, see Danbolt, 2001).

We did not detect EAAC1 in astrocytes, oligodendrocytes, or other glial cells, indicating that EAAC1 is a uniquely neuronal transporter. This is in agreement with many (Kanai and Hediger, 1992; Rothstein et al., 1994; Coco et al., 1997; Shashidharan et al., 1997; Torp et al., 1997; Berger and Hediger, 1998; Plachez et al., 2000; Holmseth et al., 2005), but not all (Conti et al., 1998; Kugler and Schmitt, 1999) previous immunocytochemical studies. The apparent immunolabeling of non-neuronal cells may, in part, be explained by the tendency of a part of the EAAC1 sequence (IVNPFALEPTILDNEDSDTK) to induce generation of antibodies that cross-react with tubulin (Holmseth et al., 2005).

\section{Is EAAC1 present in nerve terminals?}

EAAC1 is not detectable in glutamatergic terminals using immunocytochemistry as shown here and by others (Rothstein et al., 1994; Shashidharan et al., 1997; Conti et al., 1998; Holmseth et al., 2005), in agreement with observation that the $C$ terminus of EAAC1 contains a sorting motif directing it to dendrites rather than to axon terminals (Cheng et al., 2002). Furthermore, there is no glutamate uptake activity in glutamatergic terminals in GLT1-deficient mice (Furness et al., 2008).

In GABAergic terminals, however, the situation is more complex. Some immunocytochemical studies conducted before EAAC1 knock-out mice became available noted labeling of GABAergic terminals (He et al., 2000, 2001) in the deep cerebellar nuclei (Rothstein et al., 1994). A study based on antisense knockdown concluded that EAAC1 is important for GABA synthesis in GABAergic terminals (Sepkuty et al., 2002), but the antisense probes used may have had unrecognized effects because EAAC1 knockdown using the same method (Rothstein et al., 1996) lead to a larger reduction in glutamate uptake activity than can be attributed to this transporter (see data in the studies by Danbolt et al., 1992; Haugeto et al., 1996; Bergles and Jahr, 1997, 1998; Peghini et al., 1997; Tanaka et al., 1997; Furness et al., 2008; Sun et al., 2011).

However, functional data (Mathews and Diamond, 2003; Stafford et al., 2010) showed that raising the extracellular glutamate levels, increases mIPSC amplitudes. This suggests that EAAC1-mediated glutamate uptake in GABAergic terminals provides glutamate for GABA synthesis increasing GABA levels. Although Stafford et al. (2010) also failed to detect EAAC1 protein in terminals by means of immunocytochemistry, they found that 
exogenous D-aspartate could accumulate in GABA-containing terminals when GLT-1 was inhibited, suggesting that interneuron terminals have glutamate uptake capacity. The question remains whether this is due to EAAC1 molecules that have evaded detection with the antibodies or whether this uptake is due to another transporter.

\section{EAAC1 is present in spines, but is not concentrated there}

A comparison of the pattern of EAAC1 immunolabeling (Fig. 7A) with the distribution of EAAT4 (Fig. 7B) [Dehnes et al. (1998), their Figs. 4, 6] indicates that EAAC1 is not concentrated in dendritic spines (Fig. 13). Although it is possible that the epitope in EAAC1 recognized by this C-terminal antibody is obscured through an interaction with an accessory protein in the dendrites, our findings are in accordance with the distribution observed using monoclonal antibodies against a peptide corresponding to amino acid residues 161-177 of EAAC1 [Shashidharan et al. (1997), their Fig. 4].

In order for transporters to participate in clearance of extracellular glutamate, they must be localized to the plasma membrane. GLT1, GLAST (Lehre and Danbolt, 1998), and EAAT4 (Dehnes et al., 1998) are highly enriched at the cell surface, and transporter-mediated currents can be recorded from astrocytes (Bergles and Jahr, 1997; Huang et al., 2004) and Purkinje cells (Otis et al., 1997) in response to application of substrates or following synaptic release, supporting a role for these transporters in glutamate clearance. In contrast, EAAC1 immunoreactivity was predominantly intracellular. This observation is unlikely to be an artifact, because Shashidharan et al. (1997) observed a similar localization of EAAC1 using a different antibody (see above) and because EAAC1 was readily detected in the brush border in the kidney. Furthermore, cell culture studies indicate that only $20-30 \%$ of EAAC1 is localized at the plasma membrane (Fournier et al., 2004; Sheldon et al., 2006), and can be inserted into the plasma membrane in response to activity (González et al., 2007; D’Amico et al., 2010; Ross et al., 2011).

\section{The contribution of EAAC1 to synaptic glutamate clearance}

As shown here, the mean EAAC1 density (in hippocampus of young adult rats) was $\sim 90$ transporters $/ \mu \mathrm{m}^{2}$ dendritic membrane, provided all EAAC1 is inserted into the membrane, or $\sim 130$ molecules per synapse. As several thousand molecules of glutamate are released from each vesicle, it appears unlikely that there are enough EAAC1 transporters to have an appreciable effect on glutamate clearance in the brain, in agreement with our electrophysiological results [i.e., the lack of detectable glutamate uptake currents in hippocampal pyramidal cells (Bergles and Jahr, 1998) and the lack of significant differences between such currents in pyramidal neurons from wild-type and EAAC1knock-out mice]. Furthermore, the low glutamate uptake activity in GLT-1-deficient mice and the low uptake activity in spines also point to a negligible contribution from EAAC1.

The results presented here suggest that GLT-1, GLAST, and EAAC1 represent, respectively, $\sim 80,20$, and $1 \%$ of all glutamate transporter proteins in the young adult hippocampus. Because GLAST and EAAC1 are $\sim 6$ and 1.5 times slower than GLT-1 (Grewer and Rauen, 2005), respectively, it follows that the effective contribution to uptake activity is dominated by GLT-1 (>95\%), in agreement with previous data (Haugeto et al., 1996; Tanaka et al., 1997; Huang et al., 2004).

\section{Is perisynaptic EAAC1 able to buffer released glutamate?}

Scimemi et al. (2009) described functional differences in synaptic currents in hippocampal slices from wild-type and EAAC1knock-out mice, and proposed a model whereby perisynaptic EAAC1 buffers glutamate released during synaptic events and prolongs the time course of its clearance by astrocytes. Without significantly altering activation of receptors in the synaptic cleft, EAAC1 reduces recruitment of perisynaptic/extrasynaptic NR2B-containing NMDARs, thereby facilitating induction of long-term potentiation by short bursts of high-frequency stimulation. If the intrinsic $K_{\mathrm{d}}$ for glutamate binding is $200 \mu \mathrm{M}$ (Grewer and Rauen, 2005; Grewer et al., 2008), then rapid buffering is possible at the concentration expected perisynaptically after release (Danbolt, 2001; Scimemi and Beato, 2009) even though the turnover or cycling rate of EAAC1 (Grewer et al., 2000) is not dramatically different from GLT-1 and GLAST (Wadiche et al., 1995; Wadiche and Kavanaugh, 1998). In addition, recent studies indicate that EAAC1 regulates the abundance of AMPA receptors at synapses formed between young cortical neurons in vitro by regulating the activation of perisynaptic NR2B-containing NMDA receptors (Jarzylo and Man, 2012), further supporting a role for EAAC1 in controlling the availability of glutamate released at synapses. However, simulations (Scimemi et al., 2009) suggest that a high density of EAAC1 transporters is required to significantly influence the occupancy of receptors in this domain. The apparent discrepancy between the low abundance of EAAC1 and the ability of this transporter to contribute to extracellular glutamate dynamics, is at present unresolved.

\section{Does EAAC1 participate in other aspects of cell physiology?}

The highest expression levels of EAAC1 are in the small intestine and in the kidney, where EAAC1 contributes to absorption of amino acids. Furthermore, EAAC1 also enables neurons to take up cysteine for glutathione synthesis and it thereby may prevent cell stress and premature aging (Chen and Swanson, 2003; Aoyama et al., 2006; Berman et al., 2011). These three roles may be sufficient to explain the evolutionary preservation of the $\mathrm{EAAC1}$ gene and point to a prominent role for EAAC1 in metabolic processes.

\section{References}

Aoyama K, Suh SW, Hamby AM, Liu J, Chan WY, Chen Y, Swanson RA (2006) Neuronal glutathione deficiency and age-dependent neurodegeneration in the EAAC1 deficient mouse. Nat Neurosci 9:119-126.

Bailey CG, Ryan RM, Thoeng AD, Ng C, King K, Vanslambrouck JM, AurayBlais C, Vandenberg RJ, Bröer S, Rasko JE (2011) Loss-of-function mutations in the glutamate transporter SLC1A1 cause human dicarboxylic aminoaciduria. J Clin Invest 121:446-453.

Banner SJ, Fray AE, Ince PG, Steward M, Cookson MR, Shaw PJ (2002) The expression of the glutamate re-uptake transporter excitatory amino acid transporter 1 (EAAT1) in the normal human CNS and in motor neurone disease: an immunohistochemical study. Neuroscience 109:27-44.

Beckstrøm H, Julsrud L, Haugeto O, Dewar D, Graham DI, Lehre KP, StormMathisen J, Danbolt NC (1999) Interindividual differences in the levels of the glutamate transporters GLAST and GLT, but no clear correlation with Alzheimer's disease. J Neurosci Res 55:218-229.

Berger UV, Hediger MA (1998) Comparative analysis of glutamate transporter expression in rat brain using differential double in situ hybridization. Anat Embryol (Berl) 198:13-30.

Bergles DE, Jahr CE (1997) Synaptic activation of glutamate transporters in hippocampal astrocytes. Neuron 19:1297-1308.

Bergles DE, Jahr CE (1998) Glial contribution to glutamate uptake at Schaffer collateral-commissural synapses in the hippocampus. J Neurosci 18:7709-7716.

Bergles DE, Tzingounis AV, Jahr CE (2002) Comparison of coupled and uncoupled currents during glutamate uptake by GLT-1 transporters. J Neurosci 22:10153-10162. 
Berman AE, Chan WY, Brennan AM, Reyes RC, Adler BL, Suh SW, Kauppinen TM, Edling Y, Swanson RA (2011) N-Acetylcysteine prevents loss of dopaminergic neurons in the $\mathrm{EAACl}^{-1-}$ mouse. Ann Neurol 69:509-520.

Bjørås M, Gjesdal O, Erickson JD, Torp R, Levy LM, Ottersen OP, Degree M, Storm-Mathisen J, Seeberg E, Danbolt NC (1996) Cloning and expression of a neuronal rat brain glutamate transporter. Brain Res Mol Brain Res 36:163-168.

Chaudhry FA, Lehre KP, van Lookeren Campagne M, Ottersen OP, Danbolt NC, Storm-Mathisen J (1995) Glutamate transporters in glial plasma membranes: highly differentiated localizations revealed by quantitative ultrastructural immunocytochemistry. Neuron 15:711-720.

Chen Y, Swanson RA (2003) The glutamate transporters EAAT2 and EAAT3 mediate cysteine uptake in cortical neuron cultures. J Neurochem 84:1332-1339.

Cheng C, Glover G, Banker G, Amara SG (2002) A novel sorting motif in the glutamate transporter excitatory amino acid transporter 3 directs its targeting in Madin-Darby canine kidney cells and hippocampal neurons. J Neurosci 22:10643-10652.

Coco S, Verderio C, Trotti D, Rothstein JD, Volterra A, Matteoli M (1997) Non-synaptic localization of the glutamate transporter EAAC1 in cultured hippocampal neurons. Eur J Neurosci 9:1902-1910.

Conti F, DeBiasi S, Minelli A, Rothstein JD, Melone M (1998) EAAC1, a high-affinity glutamate transporter, is localized to astrocytes and GABAergic neurons besides pyramidal cells in the rat cerebral cortex. Cereb Cortex 8:108-116.

D’Amico A, Soragna A, Di Cairano E, Panzeri N, Anzai N, Vellea Sacchi F, Perego C (2010) The surface density of the glutamate transporter EAAC1 is controlled by interactions with PDZK1 and AP2 adaptor complexes. Traffic 11:1455-1470.

Danbolt NC (2001) Glutamate uptake. Prog Neurobiol 65:1-105.

Danbolt NC, Pines G, Kanner BI (1990) Purification and reconstitution of the sodium- and potassium-coupled glutamate transport glycoprotein from rat brain. Biochemistry 29:6734-6740.

Danbolt NC, Storm-Mathisen J, Kanner BI (1992) An $\left[\mathrm{Na}^{+}+\mathrm{K}^{+}\right]$coupled $\mathrm{L}$-glutamate transporter purified from rat brain is located in glial cell processes. Neuroscience 51:295-310.

Danbolt NC, Lehre KP, Dehnes Y, Chaudhry FA, Levy LM (1998) Localization of transporters using transporter-specific antibodies. Methods Enzymol 296:388-407.

Davies LP, Johnston GA (1976) Uptake and release of D- and L-aspartate by rat brain slices. J Neurochem 26:1007-1014.

Dehnes Y, Chaudhry FA, Ullensvang K, Lehre KP, Storm-Mathisen J, Danbolt NC (1998) The glutamate transporter EAAT4 in rat cerebellar Purkinje cells: a glutamate-gated chloride channel concentrated near the synapse in parts of the dendritic membrane facing astroglia. J Neurosci 18:3606-3619.

Fournier KM, González MI, Robinson MB (2004) Rapid trafficking of the neuronal glutamate transporter, EAAC1: evidence for distinct trafficking pathways differentially regulated by protein kinase $\mathrm{C}$ and platelet-derived growth factor. J Biol Chem 279:34505-34513.

Furness DN, Dehnes Y, Akhtar AQ, Rossi DJ, Hamann M, Grutle NJ, Gundersen V, Holmseth S, Lehre KP, Ullensvang K, Wojewodzic M, Zhou Y, Attwell D, Danbolt NC (2008) A quantitative assessment of glutamate uptake into hippocampal synaptic terminals and astrocytes: new insights into a neuronal role for excitatory amino acid transporter 2 (EAAT2). Neuroscience 157:80-94.

Furuta A, Rothstein JD, Martin LJ (1997) Glutamate transporter protein subtypes are expressed differentially during rat CNS development. J Neurosci 17:8363-8375.

González MI, Krizman-Genda E, Robinson MB (2007) Caveolin-1 regulates the delivery and endocytosis of the glutamate transporter, excitatory amino acid carrier 1. J Biol Chem 282:29855-29865.

Grewer C, Rauen T (2005) Electrogenic glutamate transporters in the CNS: molecular mechanism, pre-steady-state kinetics, and their impact on synaptic signaling. J Membr Biol 203:1-20.

Grewer C, Watzke N, Wiessner M, Rauen T (2000) Glutamate translocation of the neuronal glutamate transporter EAAC1 occurs within milliseconds. Proc Natl Acad Sci U S A 97:9706-9711.

Grewer C, Gameiro A, Zhang Z, Tao Z, Braams S, Rauen T (2008) Glutamate forward and reverse transport: from molecular mechanism to transporter-mediated release after ischemia. IUBMB Life 60:609-619.
Haugeto Ø, Ullensvang K, Levy LM, Chaudhry FA, Honoré T, Nielsen M, Lehre KP, Danbolt NC (1996) Brain glutamate transporter proteins form homomultimers. J Biol Chem 271:27715-27722.

He Y, Janssen WG, Rothstein JD, Morrison JH (2000) Differential synaptic localization of the glutamate transporter EAAC1 and glutamate receptor subunit GluR2 in the rat hippocampus. J Comp Neurol 418:255-269.

He Y, Hof PR, Janssen WG, Rothstein JD, Morrison JH (2001) Differential synaptic localization of GluR2 and EAAC1 in the macaque monkey entorhinal cortex: a postembedding immunogold study. Neurosci Lett 311:161-164.

Holmseth S, Dehnes Y, Bjørnsen LP, Boulland JL, Furness DN, Bergles D, Danbolt NC (2005) Specificity of antibodies: unexpected cross reactivity of antibodies directed against the EAAT3 (EAAC) glutamate transporter. Neuroscience 136:649-660.

Holmseth S, Lehre KP, Danbolt NC (2006) Specificity controls for immunocytochemistry. Anat Embryol (Berl) 211:257-266.

Holmseth S, Scott HA, Real K, Lehre KP, Leergaard TB, Bjaalie JG, Danbolt NC (2009) The concentrations and distributions of three C-terminal variants of the GLT1 (EAAT2; slc1a2) glutamate transporter protein in rat brain tissue suggest differential regulation. Neuroscience 162:1055-1071.

Holmseth S, Zhou Y, Follin-Arbelet VV, Lehre KP, Bergles DE, Danbolt NC (2012) Specificity controls for immunocytochemistry: the antigen preadsorption test can lead to inaccurate assessment of antibody specificity. J Histochem Cytochem 60:174-187.

Huang YH, Sinha SR, Tanaka K, Rothstein JD, Bergles DE (2004) Astrocyte glutamate transporters regulate metabotropic glutamate receptormediated excitation of hippocampal interneurons. J Neurosci 24:4551-4559.

Huang YH, Sinha SR, Fedoryak OD, Ellis-Davies GC, Bergles DE (2005) Synthesis and characterization of 4-methoxy-7-nitroindolinyl-Daspartate, a caged compound for selective activation of glutamate transporters and $N$-methyl-D-aspartate receptors in brain tissue. Biochemistry 44:3316-3326.

Jarzylo LA, Man HY (2012) Parasynaptic NMDA receptor signaling couples neuronal glutamate transporter function to AMPA receptor synaptic distribution and stability. J Neurosci 32:2552-2563.

Kanai Y, Hediger MA (1992) Primary structure and functional characterization of a high-affinity glutamate transporter. Nature 360:467-471.

Kugler P, Schmitt A (1999) Glutamate transporter EAAC1 is expressed in neurons and glial cells in the rat nervous system. Glia 27:129-142.

Lee S, Park SH, Zuo Z (2012) Effects of isoflurane on learning and memory functions of wild-type and glutamate transporter type 3 knockout mice. J Pharm Pharmacol 64:302-307.

Lehre AC, Rowley NM, Zhou Y, Holmseth S, Guo C, Holen T, Hua R, Laake P, Olofsson AM, Poblete-Naredo I, Rusakov DA, Madsen KK, Clausen RP, Schousboe A, White HS, Danbolt NC (2011) Deletion of the betaine-GABA transporter (BGT1; slc6a12) gene does not affect seizure thresholds of adult mice. Epilepsy Res 95:70-81.

Lehre KP, Danbolt NC (1998) The number of glutamate transporter subtype molecules at glutamatergic synapses: chemical and stereological quantification in young adult rat brain. J Neurosci 18:8751-8757.

Lehre KP, Levy LM, Ottersen OP, Storm-Mathisen J, Danbolt NC (1995) Differential expression of two glial glutamate transporters in the rat brain: quantitative and immunocytochemical observations. J Neurosci 15:1835-1853.

Levy LM, Lehre KP, Rolstad B, Danbolt NC (1993) A monoclonal antibody raised against an $\left[\mathrm{Na}^{+}-\mathrm{K}^{+}\right]$coupled L-glutamate transporter purified from rat brain confirms glial cell localization. FEBS Lett 317:79-84.

Lowry OH (1953) The quantitative histochemistry of the brain. J Histochem Cytochem 1:420-428.

Lowry OH, Roberts NR, Leiner KY, Wu ML, Farr AL, Albers RW (1954) The quantitative histochemistry of brain. III. Ammon's horn. J Biol Chem 207:39-49.

Mathews GC, Diamond JS (2003) Neuronal glutamate uptake contributes to GABA synthesis and inhibitory synaptic strength. J Neurosci 23:2040-2048.

Milton ID, Banner SJ, Ince PG, Piggott NH, Fray AE, Thatcher N, Horne CH, Shaw PJ (1997) Expression of the glial glutamate transporter EAAT2 in the human CNS: an immunohistochemical study. Brain Res Mol Brain Res 52:17-31.

Otis TS, Kavanaugh MP, Jahr CE (1997) Postsynaptic glutamate transport at the climbing fiber Purkinje cell synapse. Science 277:1515-1518. 
Palay SL, Chan-Palay V (1974) Cerebellar cortex: cytology and organization, p 348. Berlin, Heidelberg, New York: PC Springer.

Peghini P, Janzen J, Stoffel W (1997) Glutamate transporter EAAC-1deficient mice develop dicarboxylic aminoaciduria and behavioral abnormalities but no neurodegeneration. EMBO J 16:3822-3832.

Peters A, Palay SL, Webster HF (1991) The fine structure of the nervous system: neurons and their supporting cells, p 512. New York, Oxford: Oxford UP.

Pines G, Danbolt NC, Bjørås M, Zhang Y, Bendahan A, Eide L, Koepsell H, Storm-Mathisen J, Seeberg E, Kanner BI (1992) Cloning and expression of a rat brain L-glutamate transporter. Nature 360:464-467.

Plachez C, Danbolt NC, Récasens M (2000) Transient expression of the glial glutamate transporters GLAST and GLT in hippocampal neurons in primary culture. J Neurosci Res 59:587-593.

Ross JR, Porter BE, Buckley PT, Eberwine JH, Robinson MB (2011) mRNA for the EAAC1 subtype of glutamate transporter is present in neuronal dendrites in vitro and dramatically increases in vivo after a seizure. Neurochem Int 58:366-375.

Rothstein JD, Martin L, Levey AI, Dykes-Hoberg M, Jin L, Wu D, Nash N, Kuncl RW (1994) Localization of neuronal and glial glutamate transporters. Neuron 13:713-725.

Rothstein JD, Dykes-Hoberg M, Pardo CA, Bristol LA, Jin L, Kuncl RW, Kanai Y, Hediger MA, Wang Y, Schielke JP, Welty DF (1996) Knockout of glutamate transporters reveals a major role for astroglial transport in excitotoxicity and clearance of glutamate. Neuron 16:675-686.

Scimemi A, Beato M (2009) Determining the neurotransmitter concentration profile at active synapses. Mol Neurobiol 40:289-306.

Scimemi A, Tian H, Diamond JS (2009) Neuronal transporters regulate glutamate clearance, NMDA receptor activation, and synaptic plasticity in the hippocampus. J Neurosci 29:14581-14595.

Sepkuty JP, Cohen AS, Eccles C, Rafiq A, Behar K, Ganel R, Coulter DA, Rothstein JD (2002) A neuronal glutamate transporter contributes to neurotransmitter GABA synthesis and epilepsy. J Neurosci 22:6372-6379.

Shashidharan P, Huntley GW, Murray JM, Buku A, Moran T, Walsh MJ, Morrison JH, Plaitakis A (1997) Immunohistochemical localization of the neuron-specific glutamate transporter EAAC1 (EAAT3) in rat brain and spinal cord revealed by a novel monoclonal antibody. Brain Res 773:139-148.

Sheldon AL, González MI, Robinson MB (2006) A carboxyl-terminal determinant of the neuronal glutamate transporter, EAAC1, is required for platelet-derived growth factor-dependent trafficking. J Biol Chem 281:4876-4886.

Stafford MM, Brown MN, Mishra P, Stanwood GD, Mathews GC (2010) Glutamate spillover augments GABA synthesis and release from axodendritic synapses in rat hippocampus. Hippocampus 20:134-144.

Storck T, Schulte S, Hofmann K, Stoffel W (1992) Structure, expression, and functional analysis of a $\mathrm{Na}^{+}$-dependent glutamate/aspartate transporter from rat brain. Proc Natl Acad Sci U S A 89:10955-10959.

Sun W, Hoffman KM, Holley DC, Kavanaugh MP (2011) Specificity and actions of an arylaspartate inhibitor of glutamate transport at the Schaffer collateral-CA1 pyramidal cell synapse. PLoS One 6:e23765.

Takagaki G (1978) Sodium and potassium ions and accumulation of labelled D-aspartate and GABA in crude synaptosomal fraction from rat cerebral cortex. J Neurochem 30:47-56.

Tanaka K, Watase K, Manabe T, Yamada K, Watanabe M, Takahashi K, Iwama H, Nishikawa T, Ichihara N, Kikuchi T, Okuyama S, Kawashima N, Hori S, Takimoto M, Wada K (1997) Epilepsy and exacerbation of brain injury in mice lacking the glutamate transporter GLT-1. Science 276:1699-1702

Torp R, Hoover F, Danbolt NC, Storm-Mathisen J, Ottersen OP (1997) Differential distribution of the glutamate transporters GLT1 and rEAAC1 in rat cerebral cortex and thalamus: an in situ hybridization analysis. Anat Embryol (Berl) 195:317-326.

Trotti D, Volterra A, Lehre KP, Rossi D, Gjesdal O, Racagni G, Danbolt NC (1995) Arachidonic acid inhibits a purified and reconstituted glutamate transporter directly from the water phase and not via the phospholipid membrane. J Biol Chem 270:9890-9895.

Ullensvang K, Lehre KP, Storm-Mathisen J, Danbolt NC (1997) Differential developmental expression of the two rat brain glutamate transporter proteins GLAST and GLT. Eur J Neurosci 9:1646-1655.

Wadiche JI, Kavanaugh MP (1998) Macroscopic and microscopic properties of a cloned glutamate transporter chloride channel. J Neurosci 18:7650-7661.

Wadiche JI, Arriza JL, Amara SG, Kavanaugh MP (1995) Kinetics of a human glutamate transporter. Neuron 14:1019-1027.

Watase K, Hashimoto K, Kano M, Yamada K, Watanabe M, Inoue Y, Okuyama S, Sakagawa T, Ogawa S, Kawashima N, Hori S, Takimoto M, Wada K, Tanaka K (1998) Motor discoordination and increased susceptibility to cerebellar injury in GLAST mutant mice. Eur J Neurosci 10:976-988.

Weibel ER (1979) Stereological methods, Vol 1. Practical methods for biological morphometry. London: Academic. 